\title{
Overview of Environmental and Hydrogeologic Conditions at Sitka, Alaska
}

\author{
U.S. GEOLOGICAL SURVEY
}

Open-File Report 95-345

Prepared in cooperation with the

FEDERAL AVIATION ADMINISTRATION

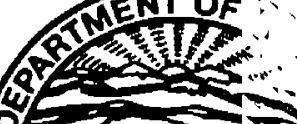




\title{
Overview of Environmental and
}

\section{Hydrogeologic Conditions at Sitka, Alaska}

\author{
By Eppie V. Hogan
}

U.S. GEOLOGICAL SURVEY

Open-File Report 95-345

Prepared in cooperation with the

FEDERAL AVIATION ADMINISTRATION

Anchorage, Alaska

1995 


\title{
U.S. DEPARTMENT OF THE INTERIOR BRUCE BABBITT, Secretary
}

\author{
U.S. GEOLOGICAL SURVEY
}

Gordon P. Eaton, Director

For additional information write to:

District Chief

U.S. Geological Survey

4230 University Drive, Suite 201

Anchorage, AK 99508-4664
Copies of this report may be purchased from:

U.S. Geological Survey

Earth Science Information Center

Open-File Reports Section

Box 25286, MS 517

Federal Center

Denver, CO 80225-0425 


\section{CONTENTS}

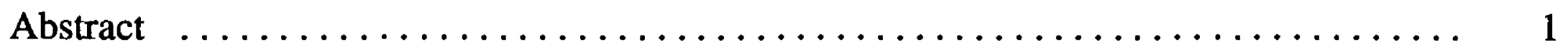

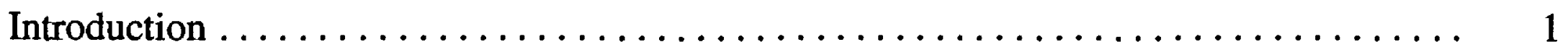

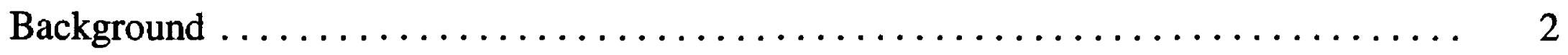

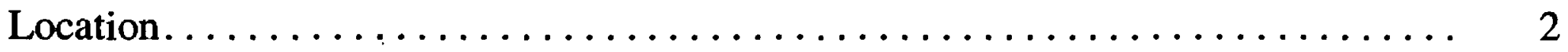

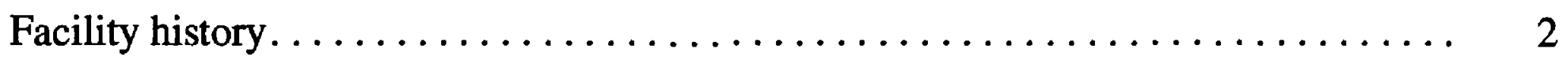

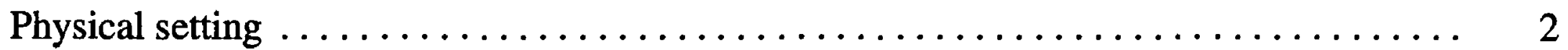

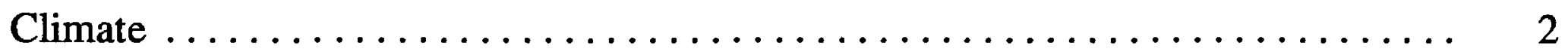

Vegetation $\ldots \ldots \ldots \ldots \ldots \ldots \ldots \ldots \ldots \ldots \ldots \ldots \ldots \ldots \ldots \ldots \ldots, 4$

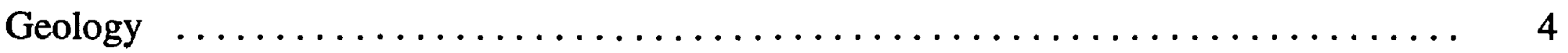

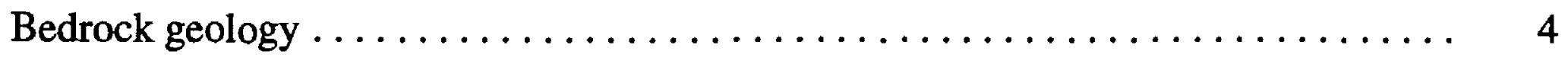

Surficial geology and soils $\ldots \ldots \ldots \ldots \ldots \ldots \ldots \ldots \ldots \ldots \ldots \ldots \ldots \ldots, 4$

Earthquakes ......................................... 5

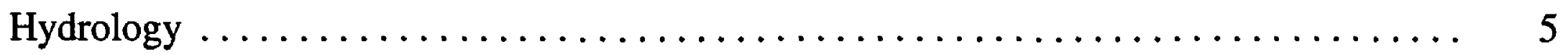

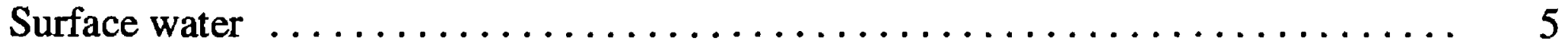

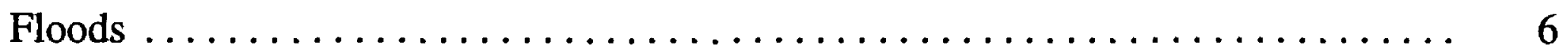

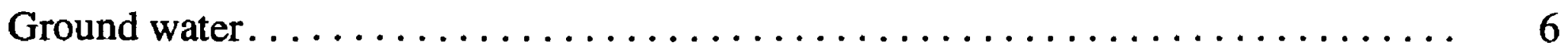

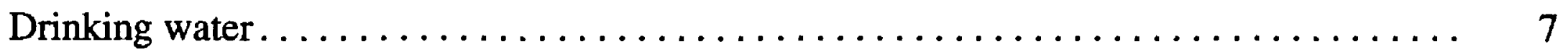

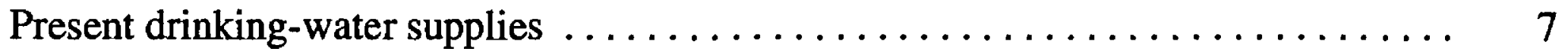

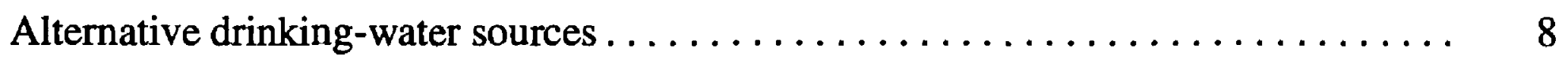

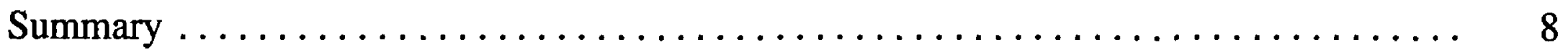

References cited..................................... 9

Appendix 1. Text of a 1942 letter to the Navy regarding the availability of ground water on Japonski Island $\ldots \ldots \ldots \ldots \ldots \ldots \ldots \ldots \ldots \ldots \ldots \ldots \ldots \ldots$

Appendix 2. Water-quality data for surface water near Sitka, Alaska. ........... A-2

\section{FIGURES}

1. Map showing location of Sitka, Alaska, and the Federal Aviation Administration facility

\section{TABLES}

1. Mean monthly and annual temperature, precipitation and snowfall for the period 1948-87, Sitka, Alaska . . . . . . . . . . . . . . . . . . . . . . . . . .

2. Mean monthly flow at stream-gaging station 15087690 , the Indian River near Sitka, Alaska, water years $1980-93 \ldots \ldots \ldots \ldots \ldots \ldots . \ldots 6$

3. Selected water-quality data from Blue Lake near Sitka, Alaska ............ 7

4. Selected water-quality data for alternative drinking-water sources near Sitka, Alaska 


\section{CONVERSION FACTORS, VERTICAL DATUM, AND ABBREVIATIONS}

\begin{tabular}{lll}
\hline Multiply & By & To obtaln \\
\hline centimeter $(\mathrm{cm})$ & 0.3937 & inch \\
millimeter $(\mathrm{mm})$ & 0.03937 & inch \\
meter $(\mathrm{m})$ & 3.281 & foot \\
kilometer $(\mathrm{km})$ & 0.6214 & mile \\
square kilometer $\left(\mathrm{km}^{2}\right)$ & 0.3861 & square mile \\
liter $(\mathrm{L})$ & 0.2642 & gallon \\
liter per day $(\mathrm{L} / \mathrm{d})$ & 0.2642 & gallon per day \\
cubic meter per second $\left(\mathrm{m}^{3} / \mathrm{s}\right)$ & 35.31 & cubic foot per second \\
cubic meter per second per square kilometer & 91.4 & cubic foot per second per scuare \\
$\left.\left(\mathrm{m}^{3} / \mathrm{s}\right) / \mathrm{km}^{2}\right)$ & & mile \\
\hline
\end{tabular}

In this report, temperature is reported in degrees Celsius $\left({ }^{\circ} \mathrm{C}\right.$ ), which can be converted to degrees Fahrenheit ( $\left.\mathrm{F}\right)$ by the following equation:

$$
\mathrm{F}=1.8(\mathrm{C})+32
$$

Chemical concentration and water temperature are given only in metric units. Chemical concentration in wat $2 r$ is given in milligrams per liter $(\mathrm{mg} / \mathrm{L})$ or micrograms per liter $(\mu \mathrm{g} / \mathrm{L})$. Milligrams per liter is a unit expressing the solute mass per unit volume (liter) of water. One thousand micrograms per liter is equivalent to 1 milligram per liter.

Sea level: In this report, "sea level" refers to the National Geodetic Vertical Datum of 1929-A geodetic datcm derived from a general adjustment of the first-order level nets of the United States and Canada, formerly called Sea Level Datum of 1929. 


\title{
Overview of Environmental and Hydrogeologic Conditions at Sitka, Alaska
}

\author{
By Eppie V. Hogan
}

\begin{abstract}
The city of Sitka is in southeast Alaska on Baranof Island, about 150 kilometers sol "hwest of Juneau and about 950 kilometers southeast of Anchorage. The Federal Aviation Administration owns or operates airway support facilities on Japonski Island, about 0.8 kilometers west of Sitka. They wish to consider environmental and hydrogeologic conditions when evaluating options for environmental compliance and remediation at these facilities. The area lies in the maritime climate zone and has cool summers and mild winters. Vegetation consists primarily of coastal vestern hemlock-Sitka spruce forest. The bedrock in the Sitka area consists of graywacke, slate, and conglomerate of late Jurassic to early Cretaceous age. Surficial deposits of Quaternary age-drift, volcanic ash, muskeg, elevated delta and shore deposits, alluvial deposits, modern beach deposits, and man-made fill-overlie most of the bedrock in the Sitka area. The Indian River, Cascade Creek, Sawmill Creek, Swan Lake, Blue Lake, and an unnamed lagoon on Japonski Island are the principal surface-water bodies in the Sitka area. Ground water on Japonski Island is found within surficial deposits and bedrock. The city of Sitka and the Federal Aviation Administration facility on Japonski Island obtain drinking water from Blue Lake. Other surface-water bodies and ground water may provide alternative drinking-water sources.
\end{abstract}

\section{INTRODUCTION}

The Federal Aviation Administration (FAA) owns and (or) operates airway support and navigational facilities throughout Alaska. At many of these sites, fuels and potentially hazardous materials such as solvents, polychlorinated biphenyls, and pesticides may have been used and (or) disposed of. To determine if environmentally hazardous materials have been spilled or dispesed of at the sites, the FAA is conducting environmental studies mandated under the Comprehensive Environmental Response, Compensation, and Liability Act and the Resource Conservation and Recovery Act. To complete these more comprehensive environmental studies, the FAA requires information on the hydrology and geology of areas surrounding the sites. This report, the product of compilation, review, and summary of existing hydrologic and geologic data by $\mathrm{tl} \geqslant \mathrm{U}$.S. Geological Survey, in cooperation with the FAA, provides such information for the FAA facility and nearby areas at Sitka, Alaska. Also presented in this report are brief descriptions of FAA facility history and the physical setting of the Sitka area. 


\section{BACKGROUND}

\section{Location}

The Sitka FAA facility is on Japonski Island in southeast Alaska (fig. 1) at lat $57^{\circ} 03^{\prime} \mathrm{N}$., long $135^{\circ} 25^{\prime} \mathrm{W}$., about $150 \mathrm{~km}$ southwest of Juneau and about $950 \mathrm{~km}$ southeast of Anchorage. Japonski Island is in Sitka Sound about $0.8 \mathrm{~km}$ west of the city of Sitka which is on Baranof Island. At the greatest width, Japonski Island is about $1.1 \mathrm{~km}$ wide, and at the greatest length, is ahout 2.3 $\mathrm{km}$ long. The City of Sitka is in the Baranof Mountains, a rugged, asymmetric mounta $n$ range having a steep eastern slope and a more gradual southwest slope (Wahrhaftig, 1965). Tie Sitka area, as referenced in this report, includes the city of Sitka and Japonski Island.

\section{Facility History}

The FAA has had a facility on Japonski Island near Sitka since 1964. The FAA operates a flight service station and navigational and communication aids. The State of Alaska main ains the runway. A detailed account of FAA owned, leased, or transferred properties near Sitka and a listing of suspected sources of contamination near these properties can be found in an environmental compliance investigation report by Ecology and Environment, Inc. (1993).

\section{PHYSICAL SETTING}

\section{Climate}

Sitka has a maritime climate characterized by small temperature variations, high h'midity, abundant precipitation, wet, cool summers and relatively mild winters (Hartman and Johnson, 1984). The mean annual temperature recorded at the Sitka FAA facility for the period $19^{1} 8-87$ is $6.9^{\circ} \mathrm{C}$. Temperatures range from an August mean maximum of $16.7^{\circ} \mathrm{C}$ to a January mean minimum of $-1.5^{\circ} \mathrm{C}$ (Leslie, 1989). Mean annual precipitation is about $2,200 \mathrm{~mm}$; about $1,030 \mathrm{~mm}$ of snow falls annually (Leslie, 1989). Mean monthly and annual temperature, precipitation, and snowfall for Sitka are summarized in table 1.

Table 1. Mean monthly and annual temperature, precipitation, and snowfall, 1948-87, Sitka, Alaska. [Modified from Leslie (1989); 'C, degree Celsius]

\begin{tabular}{|c|c|c|c|c|c|c|c|c|c|c|c|c|c|}
\hline & Jan. & Feb. & Mar. & Apr. & May & June & July & Aug. & Sept. & Oct. & Nov. & Dec. & Annual \\
\hline \multicolumn{14}{|c|}{ Temperature (C) } \\
\hline \multirow[t]{2}{*}{ Mean maximum } & 3.2 & 4.5 & 5.9 & 8.5 & 11.8 & 14.2 & 16.1 & 16.7 & 14.6 & 10.2 & 6.2 & 3.9 & 9.7 \\
\hline & \multicolumn{13}{|c|}{ (Record maximum $31.1^{\circ} \mathrm{C}$, July 1976 ) } \\
\hline \multirow[t]{2}{*}{ Mean minimum } & -1.5 & -0.6 & 1.9 & 1.9 & 5.0 & 8.1 & 10.5 & 10.9 & 8.7 & 5.2 & 1.6 & -0.3 & 4.2 \\
\hline & \multicolumn{13}{|c|}{ (Record minimum $-18.3^{\circ} \mathrm{C}$, February 1948 ) } \\
\hline Mean & 0.8 & 1.9 & 3.1 & 5.3 & 8.4 & 11.1 & 13.3 & 13.8 & 11.7 & 7.7 & 3.9 & 1.8 & 6.9 \\
\hline \multicolumn{14}{|c|}{ Precipitation, in millimeters of moisture } \\
\hline & 185 & 157 & 152 & 131 & 122 & 94.2 & 112 & 176 & 272.3 & 348 & 239 & 217 & $\begin{array}{l}\text { Total } \\
2,200\end{array}$ \\
\hline \multicolumn{14}{|c|}{ Snowfall, in millimeters } \\
\hline & 252 & 216 & 198 & 43.2 & 2.5 & 0.0 & 0.0 & 0.0 & 0.0 & 5.1 & 73.7 & 244 & $\begin{array}{c}\text { Total } \\
1,030\end{array}$ \\
\hline
\end{tabular}




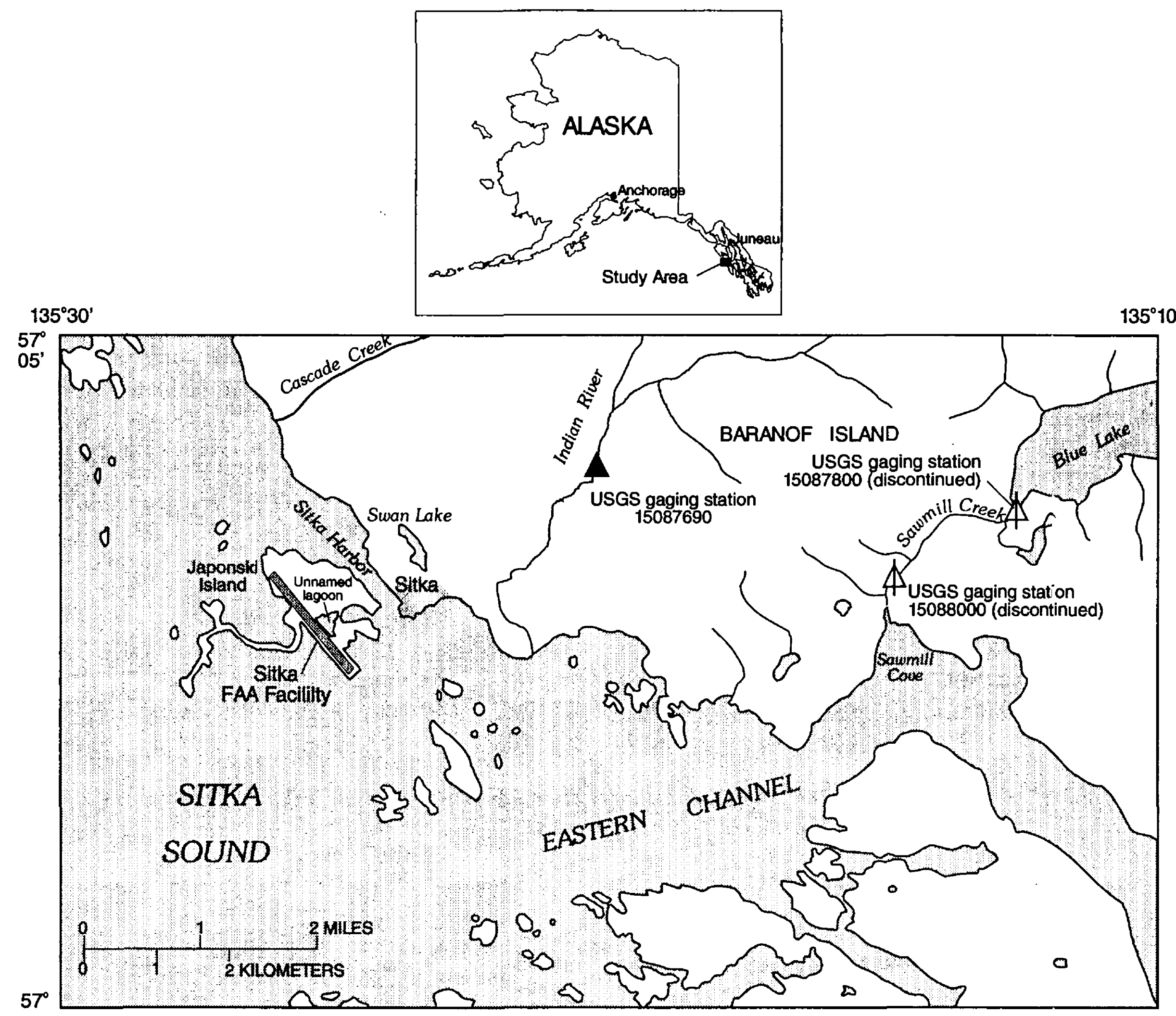

Base from U.S.Geological Suney, Sitka (A-4, A-5), Alaska, 1:63,360, 1951.

Figure 1. Location of Sitka, Alaska and the Federal Aviation Administration facility. 


\section{Vegetation}

Vegetation near Sitka consists primarily of coastal western hemlock-Sitka spruco forest, characterized by an overstory of Sitka spruce, western hemlock, and Alaska yellow cedar and an understory of ferns, lichens, and mosses (Selkregg, 1976; Viereck and Little, 1972). Exfanses of subtidal wetlands exist in numerous places on Japonski Island, including the area surrourding the FAA facility runway. Wetland vegetation consists of silverweed, hairgrass, yarrow, buttercup, and a variety of sedges. The area is part of the Tongass National Forest.

\section{GEOLOGY}

\section{Bedrock Geology}

The bedrock in the Sitka area consists of graywacke, slate, and conglomerate of late Jurassic to early Cretaceous age (Yehle, 1974; Berg and Gehrels, 1992). In some areas, these rocks are intruded by felsic dikes. Bedrock exposures are common in tidal areas where wave action has eroded the overlying surficial material (Yehle, 1974). Depth to bedrock ranges from $1.5 \mathrm{~m}$ to greater than $9 \mathrm{~m}$ below the land surface (Yehle, 1974). The general topography of the area suggests a land emergence ranging from 15 to $250 \mathrm{~m}$ above sea level (Yehle, 1974). The uplift rate in Sitka is about $0.002 \mathrm{~m} / \mathrm{yr}$ (Yehle, 1974).

\section{Surficial Geology and Solls}

With the exception of areas subjected to tidal influences, surficial deposits of Quaternary age overlie most of the bedrock in the Sitka area (Yehle, 1974). Seven distinct units identified on Japonski Island were drift, volcanic ash, muskeg, elevated delta and shore deposits, alluvial deposits, modern beach deposits, and man-made fill (Yehle, 1974).

The drift is mostly till, and consists of gravel, cobbles, and boulders, in a matrix of silt, sand, and clay (Yehle, 1974). The till deposits near Sitka are about $3 \mathrm{~m}$ thick and were deposite during Quaternary glaciation of the area. Volcanic ash deposits are and reddish-yellow in color and consist of silt, sand, minor amounts of clay-size particles, and lapilli. The volcanic ash was erup ${ }^{+}$ed from Mt. Edgecumbe on Kruzof Island, about $25 \mathrm{~km}$ to the east, and nearby volcanoes on Baranof Island. The ash deposits range from 1.5 to $3.4 \mathrm{~m}$ in thickness (Yehle, 1974). Muskeg deposits consist of partially decomposed organic material and peat. These deposits occupy lowland areas and may be as much as $9 \mathrm{~m}$ thick. Elevated delta and shore deposits consist of loose, well-bedded sandy gravel found in delta zones and along shorelines on Japonski Island. Delta and shore deposits range in thickness from 1.5 to $6 \mathrm{~m}$ (Yehle, 1974). Alluvial deposits consist of well-sorted sandy gravel and some cobbles. These deposits are found along streams on Japonski Island, where the thickness ranges from 2.5 to $4.6 \mathrm{~m}$ (Yehle, 1974). Modern beach deposits consist of various mixtures of gravel, cobbles, sand, and boulders, ranging from 1.5 to $4.5 \mathrm{~m}$ in thicknsss. The distribution of modern beach deposits is widespread in the Sitka area except along the southwestern edge of Japonski Island. Man-made fill consists of sand, gravel, till, $b^{1}$ ncks of bedrock, muskeg, and volcanic ash. These deposits surround the runway and all otl or FAA facilities on Japonski Island and may be as much as $20 \mathrm{~m}$ thick (Yehle, 1974). 
The soils of the Sitka area are similar to those found throughout southeast Alaska and are of two principal types: soils formed on volcanic ash parent material and soils found under forests of Sitka spruce and western hemlock (Rieger and others, 1979). Well-drained soils, found on low hills near Sitka, develop on thick deposits of sandy and cindery volcanic ash (Rieger and others, 1979). Loamy soils are found under forested areas near the Sitka FAA facility and are characterized by a thin, gray surface layer over thick, black to brown subsurface layers (Rieger and others, 1979). The Sitka area is free of permafrost (Ferrians, 1965).

\section{Earthquakes}

The Sitka area lies within the circum-Pacific seismic belt, a region of earthquake activity that rims the north Pacific Ocean. Southeast Alaska is cut by the Chatham Strait Fault, the Fairweather Fault, and numerous smaller faults. In recent years, several earthquakes with Richter scale magnitudes greater than 7 have been recorded along these fault systems (Brower and others. 1977; Stephens and others, 1986).

During the period 1899 to 1972, several earthquakes with Richter magnitudes of 5 or greater have been recorded within $160 \mathrm{~km}$ of Sitka (Yehle, 1974). Three of the earthquakes had a magnitude between 5 and 6, two were between 6 and 7, and three were greater than 7 (Yehle, 1974). On July 30, 1972, a major earthquake, between 7.1 and 7.6 on the Richter scale, was reported in the area. The epicenter of this earthquake was about $40 \mathrm{~km}$ from Sitka and ground motion las ${ }^{+} \mathrm{ed}$ for about 40 seconds (Yehle, 1974). Damage to Sitka was minor. The average relative displacement of buildings founded on graywacke bedrock was $0.94 \mathrm{~cm}$ (Yehle, 1974). It is assumed that earthquakes with magnitudes of 7.6 or greater will occur again in the Sitka area (Yehle, 1974).

Earthquake-induced water waves often develop during major earthquakes (Yehle, 1974). Several earthquake-induced waves ranging from 0.1 to $4.4 \mathrm{~m}$ in height have been recordec' in the Sitka area (Yehle, 1974). A 4.4-m high wave from the 1964 Alaska earthquake struck the coastline on March 27, 1964 (Yehle, 1974). Analyses of wave heights that might affect the Sitka Airport and the FAA facility were prepared by Dames and Moore (1971). A 100-year maximum wave of $6 \mathrm{~m}$ was established for the Sitka coastal area. Waves of this magnitude may reach the FAA facilities which lie near sea level along the perimeter of Japonski Island.

\section{HYDROLOGY}

\section{Surface Water}

The Indian River, Cascade Creek, Sawmill Creek, Swan Lake, Blue Lake, and an unרamed lagoon on Japonski Island are the principal surface-water bodies in the Sitka area (fig. 1). The mouth of Sawmill Creek is about $7.5 \mathrm{~km}$ east of Japonski Island. The creek flows from Blue Lake southwest to Sawmill Cove. Cascade Creek is about $2 \mathrm{~km}$ north of the island and flows southwest to Sitka Sound. The Indian River is about $1.2 \mathrm{~km}$ to the east of the island and flows southwest to the Eastern Channel. Swan Lake is about $1 \mathrm{~km}^{2}$ in size and is about $1 \mathrm{~km}$ northeast of Janonski Island. Blue Lake is about $5 \mathrm{~km}^{2}$ in size and is about $6.5 \mathrm{~km}$ east of the island. The unnamed lagoon on Japonski Island is about $0.25 \mathrm{~km}^{2}$ in area and is adjacent to the FAA facility.

Discharge of the Indian River near Sitka was reported by the U.S. Geological Survey (USGS) from 1980 to 1993 at stream-gaging station 15087690 , about $1.6 \mathrm{~km}$ northeast of the city of Sitka (fig. 1). During periods of intense snowmelt in May, mean monthly discharge was about $3.1 \mathrm{~m}^{3} / \mathrm{s}$; 
during periods of heavy rainfall in October, mean monthly discharge was $5.4 \mathrm{~m}^{3} / \mathrm{s}$; and during periods of low flow in March and April, mean discharge was about $1.9 \mathrm{~m}^{3} / \mathrm{s}$ (table 2) (U.S. Geological Survey, 1994). Annual mean flow is about $3 \mathrm{~m}^{3} / \mathrm{s}$. The Indian River drains an area of about $26 \mathrm{~km}^{2}$ upstream from the gaging station (U.S. Geological Survey, 1994). Average annual runoff is about $0.1\left(\mathrm{~m}^{3} / \mathrm{s}\right) / \mathrm{km}^{2}$ (U.S. Geological Survey, 1994). On September 4, 1990, heavy rain caused a maximum reported discharge of about $160 \mathrm{~m}^{3} / \mathrm{s}$ (Jones and Fahl, 1994).

Table 2. Mean monthly flow at stream-gaging station 15087690, the Indian River near Sitka, Alaska, water ye.ars 1980-93

[Values in cubic meters per second]

\begin{tabular}{lcccccccccccc}
\hline & Oct. & Nov. & Dec. & Jan. & Feb. & Mar. & Apr. & May & June & July & Aug. & Sept. \\
\hline Mean & 5.4 & 3.0 & 2.9 & 3.0 & 2.5 & 1.9 & 1.9 & 3.1 & 2.4 & 1.7 & 2.6 & 5.1 \\
Maximum & 8.3 & 6.2 & 5.9 & 5.2 & 4.4 & 3.5 & 3.1 & 4.7 & 4.7 & 3.1 & 6.7 & 8.3 \\
Minimum & 2.9 & 1.1 & 0.6 & 1.3 & 1.0 & 0.6 & 1.1 & 1.5 & 0.8 & 0.6 & 0.8 & 1.4 \\
\hline
\end{tabular}

From 1920 to 1957, a partial record of the streamflow in Sawmill Creek was collected by the U.S. Geological Survey at discontinued stream-gaging station 15088000 (fig. 1). The creek drains an area of about $100 \mathrm{~km}^{2}$ upstream from the gaging station. During the months of May and June, mean flow was about $19 \mathrm{~m}^{3} / \mathrm{s}$; from August to November mean flow was about $20 \mathrm{~m}^{3} / \mathrm{s}$; an 1 during low-flow periods in March and April, mean flow was about $4.7 \mathrm{~m}^{3} / \mathrm{s}$ (U.S. Geological Survey, 1958). Annual mean flow for the period of record was $13.5 \mathrm{~m}^{3} / \mathrm{s}$ (U.S Geological Survey, 1958). On September 8, 1948, heavy rains caused a maximum discharge of $200 \mathrm{~m}^{3} / \mathrm{s}$ (Jones and Fahl, 1994). Streamflow data for Cascade Creek do not exist.

The diurnal tide range, the difference in height between mean high water and mean low water on a single day, averages $3 \mathrm{~m}$ near Sitka (Brower and others, 1977). The maximum dily tide predicted to occur at Sitka is $3.8 \mathrm{~m}$ above sea level. The minimum predicted daily tide is $-0.8 \mathrm{~m}$ below sea level (Brower and others, 1977).

Floods

The city of Sitka has no known history of significant flooding caused by stream overflow or coastal flooding by storm-surge or tsunami waves (Federal Emergency Management Agency, 1981). However, local drainage can be a problem and may cause flooding in low-lying areas (U.S. Army Corps of Engineers, 1993). Tsunamis caused by the 1964 Alaska earthquake, considered to be the largest waves in recent times, produced no unusual flooding (Yehle, 1974). Flood protection along the coastline near Sitka has been achieved by establishing adequate building forndation elevations and riprapping (Federal Emergency Management Agency, 1981).

\section{Ground Water}

Ground water on Japonski Island is found within surficial deposits and bedrock. Tha glacial and volcanic deposits that cover most of the island are relatively impermeable and yield little or no ground water (Appendix 1). The bedrock on Japonski Island has very low permeability and storage capacity, but it has been extensively fractured and some ground water is present in these openings (Appendix 1). In general, the rocks appear to be more fractured in the eastern part of tha island; however, no data are available as to the depth to which these fractures may extend before bacoming tightly closed by rock pressure. 
In an effort to assess Japonski Island's ground-water potential, a 67-m-deep well was drilled in the southern part of the island in 1942 (Appendix 1). The well was drilled into highly fractured bedrock and at a depth of about $37 \mathrm{~m}$; water rose in the well to ground level. A pump was irstalled in the well and ran continually for 14 hours at a rate $0.5 \mathrm{~L} / \mathrm{s}$. Upon removing the pump, the water again rose to ground level. The concentrations of sodium in the well ranged from 1,050 to $1,800 \mathrm{mg} / \mathrm{L}$ (Appendix 1). In general, the possibility of salt-water intrusion into coastal and island aquifers increases with depth and pumping rate (Waller and Tolen, 1962)

\section{DRINKING WATER}

\section{Present Drinking-Water Supplies}

Blue Lake is about $115 \mathrm{~m}$ above sea level and is the principal drinking-water source for the city of Sitka and Japonski Island (Alaska Department of Community and Regional Affairs, 1994). The water from the lake is chlorinated and distributed through a piped system to local residents and businesses (Alaska Department of Community and Regional Affairs, 1994). The current water demand is about 12 million $\mathrm{L} / \mathrm{d}$ or about 1,400 (L/d)/person (Mark Buggins, Sitka Water and Wastewater, oral commun., 1995). The present capacity of the water system is about 23 mill ion $\mathrm{L} / \mathrm{d}$ (Mark Buggins, Sitka Water and Wastewater, oral commun., 1995). The Indian River was used in the past and remains available as an emergency drinking-water supply.

The water in Blue Lake was sampled by the U.S. Geological Survey in 1968 and 1976 at discontinued USGS stream-gaging station 15087800, Blue Lake outlet near Sitka (fig. 1; U.S. Geological Survey, 1969 and 1977). Water properties and concentrations of major ions were within current U.S. Environmental Protection Agency (USEPA) and the State of Alaska Department of Environmental Conservation (ADEC) drinking-water regulations (table 3; Appendix 2) (Salvato, 1992).

Table 3. Selected water-quality data from Blue Lake at outlet near Sitka, Alaska (USGS gaging station No. 15087800), water years 1968, 1976

\begin{tabular}{lcc}
\hline Constituent (or property) & $\begin{array}{c}\text { USEPA Drinking-water limit } \\
(\mathrm{mg} / \mathrm{L})\end{array}$ & $\begin{array}{c}\text { Concentrations in Blue Lake } \\
(\mathrm{mg} / \mathrm{L})\end{array}$ \\
\hline Chloride (Cl) & 250 & $1.9-4.0$ \\
Iron (dissolved; Fe) & 0.3 & 0.02 \\
Sulfate ( $\left.\mathrm{SO}_{4}\right)$ & 250 & $0.0-3.7$ \\
Fluoride (F) & 2 & $<0.1$ \\
Lead (Pb) & 0.005 & 0.004 \\
Total dissolved solids & 500 & $19-31$ \\
$\mathrm{pH}$ (units) & $6.5-8.5$ & $6.6-6.8$ \\
\hline
\end{tabular}




\section{Alternatlve DrinkIng-Water Sources}

Drinking-water alternatives for the FAA facility and the city of Sitka include the Indian River, Cascade Creek, Sawmill Creek, Swan Lake, the unnamed lagoon on Japonski Islard, and, to a lesser extent, ground water. The ground water near Sitka was sampled by the U.S. Geological Survey in June 1967 (table 4; Appendix 2), but the exact locations of wells are unknown. $\Gamma^{\text {'ith the }}$ exception of iron, analyses indicated that major ions and other constituents were within current drinking-water regulations (U.S. Geological Survey, 1968).

The Indian River and Sawmill Creek represent abundant sources of drinking water for the Sitka area. During months of low discharge, mean flow of the Indian River, recorded at USGS stream-gaging station 15087690 , is about $1.9 \mathrm{~m}^{3} / \mathrm{s}$ (table 2; U.S. Geological Survey, 1958 and 1994) and mean flow of Sawmill Creek, recorded at USGS stream-gaging station 15088000, is about $4.7 \mathrm{~m}^{3} / \mathrm{s}$. This is equivalent to about 200 to 400 million $\mathrm{L} / \mathrm{d}$ and is far greater than the estimated city water use of 12 million L/d.

The water in the Indian River, Cascade Creek, Sawmill Creek, and Swan Lake was sampled by the U.S. Geological Survey during various years from 1949 to 1982 (Appendix 2). V'ith the exception of lead and iron in a sample taken from Cascade Creek, major ions, dissolved metals, nutrients, and water properties were within current USEPA and ADEC drinking-water regulations (table 4). No water-quality data are available for the unnamed lagoon on Japonski Island.

Table 4. Selected water-quality data for alternative drinking-water sources near Sitka, Alaska [-, no data available]

\begin{tabular}{|c|c|c|c|c|c|}
\hline $\begin{array}{l}\text { Constituent (or } \\
\text { property) }\end{array}$ & $\begin{array}{l}\text { Concentrations in } \\
\text { ground water } \\
\text { (mg/L) } \\
1968\end{array}$ & $\begin{array}{c}\text { Concentration in } \\
\text { the Indian River } \\
\text { (mg/L) } \\
1967-82\end{array}$ & $\begin{array}{c}\text { Concentration in } \\
\text { Sawmill Creek } \\
\text { (mg/t) } \\
1949-58\end{array}$ & $\begin{array}{c}\text { Concentration in } \\
\text { Cascade Creek } \\
\text { (mg/L) } \\
1955-76\end{array}$ & $\begin{array}{c}\text { Concentrations in } \\
\text { Swan Lake } \\
\text { (mgL) } \\
1968\end{array}$ \\
\hline Chloride (Cl) & $3.5-27$ & $2.8-3.5$ & $1.0-4.0$ & $2.6-6.5$ & 8.0 \\
\hline Iron (total Fe) & $0.02-4.7$ & $0.02-0.03$ & $0.0-0.08$ & $0.04-0.94$ & --- \\
\hline Sulfate $\left(\mathrm{SO}_{4}\right)$ & $2.0-8.0$ & $0.0-6.0$ & $0.0-5.0$ & $0.0-3.6$ & 4.2 \\
\hline Fluoride $(F)$ & 0.0 & 0.0 & $0.0-0.2$ & $0.0-0.2$ & 0.1 \\
\hline Lead $(\mathrm{Pb})$ & ---- & --- & ---- & $0.0-0.009$ & ---- \\
\hline $\begin{array}{l}\text { Total dissolved } \\
\text { solids }\end{array}$ & $19-152$ & $24-26$ & $18-26$ & $19-33$ & $3 \varepsilon$ \\
\hline pH (units) & $6.8-7.2$ & $6.8-7.0$ & $5.9-7.0$ & $6.5-7.0$ & 6.7 \\
\hline
\end{tabular}

\section{SUMMARY}

Sitka and nearby Japonski Island are in southeast Alaska about $150 \mathrm{~km}$ southwest of Juneau. They lie in the maritime climate zone, characterized by cool summers and mild winters. Vegetation consists primarily of coastal western hemlock-Sitka spruce forest. The bedrock in the area consists 
of graywacke, slate, and conglomerate of late Jurassic to early Cretaceous age. Surficial ceposits of Quaternary age include drift, volcanic ash, muskeg, elevated delta and shore deposits, alluvial deposits, modern beach deposits, and man-made fill. The Indian River, Cascade Creek, S awmill Creek, Swan Lake, Blue Lake, and an unnamed lagoon on Japonski Island are the principal surfacewater bodies near Sitka. Ground water on Japonski Island is found within surficial deposits and bedrock. The city of Sitka and the FAA facility on Japonski Island obtain drinking water from Blue Lake. Other surface-water bodies and ground water may be alternative drinking-water sources. Earthquake activity presents a potential hazard for the local area.

\section{REFERENCES CITED}

Alaska Department of Community and Regional Affairs, 1994, Sitka: Alaska Department of Community and Regional Affairs Community computer data base--Sitka, $6 \mathrm{p}$.

Alaska Department of Environmental Conservation (ADEC), 1995, Alaska water-quality standards 18 AAC 70: Alaska Department of Environmental Conservation, Water-quality management section, Juneau, AK, 47 p.

Berg, H.C., and Gehrels, G.E., 1992, Geologic map of Southeastern Alaska: U.S. Geological Survey Miscellaneous Investigations Series I-1867, 1 sheet and 24 p., scale: 1:600,000.

Brower, W.A., Searby, H.W., and Wise J.L., 1977, Climatic atlas, The outer continental shelf waters and coastal regions of Alaska, volume 1: University of Alaska Anchorage, Arctic Environmental Information Center, $439 \mathrm{~F}$.

Dames and Moore, 1971, Runway extension study report for Sitka Airport--Feasibility evaluation of suhsurface conditions and physical environmental factors for proposed airport runway extension, Sitka Alaska: Ala ka State Division of Aviation, 35 p.

Ecology and Environment, Inc., 1993, Environmental Compliance Investigation Report (ECRI), Sitka FAf station, Sitka Alaska: Anchorage [Copy available from the Environmental Compliance Section, AAL-465, Federal Aviation Administration, Alaskan Regional Office, Anchorage, AK], variously paged.

Federal Emergency Management Agency, 1981, Flood insurance study--City and Borough of Sitka, Alaska· Federal Emergency Management Agency report, 23 p.

Ferrians, O.J., Jr., 1965, Permafrost map of Alaska: U.S. Geological Survey Miscellaneous Geologic Investigations Map I-445, 1 sheet, scale 1:250,000.

Hartman, C.W., and Johnson, P.R., 1984, Environmental atlas of Alaska: University of Alaska Fairbanks, In $r$ itute of Water Resources/Engineering Experiment Station, 95 p.

Jones, S.H., and Fahl, C.B., 1994, Magnitude and frequency of floods in Alaska and conterminous basins of Canada: U.S. Geological Survey Water-Resources Investigations Report 93-4179, 122 p., 2 pl.

Leslie, L.D., 1989, Alaska climate summaries (2nd ed.): University of Alaska Anchorage, Arctic Envircnmental Information and Data Center, Alaska Climate Center Technical Note 5, variously paged.

Rieger, Samuel, Schoephorster, D.B., and Furbush, C.E., 1979, Exploratory soil survey of Alaska: Soil Conservation Service report, $213 \mathrm{p}$.

Salvato, J.A., 1992, Environmental engineering and sanitation, (4th ed.): Toronto, Canada, John Wiley and Sons, Inc., $1418 \mathrm{p}$.

Selkregg, L., 1976, Alaska regional profiles--Southeast Region: Anchorage, University of Alaska, Arctic Environmental Information and Data Center, 234 p.

Stephens, C.D., Fogleman, K.A., Lahr, J.C., and Page, R.A., 1986, Seismicity in southern Alaska, in Geologic studies in Alaska: U.S. Geological Survey Circular 978, p. 81-85.

U.S. Army Corps of Engineers, 1993, Flood hazard data, Alaska communities, Alaska: U.S. Army Corps of Engineers, $335 \mathrm{p}$. 
U.S. Geological Survey, 1958, Quantity and quality of surface waters of Alaska, water year 1957: U.S. Geological Survey Water-Supply Paper 1500.

1967, Quality of surface waters of Alaska, water year 1966: U.S. Geological Survey Water-Supply Parer 1996. 1968, Quality of surface waters of Alaska, water year 1967: U.S. Geological Survey Water-Supply Parer 2016. 1969, Quality of surface waters of Alaska, water year 1968: U.S. Geological Survey Water-Supply Parer 2150. 1977, Water resources data for Alaska, water year 1976: U.S. Geological Survey Water-Data Report A K-76-1. 1983, Water resources data for Alaska, water year 1982: U.S. Geological Survey Water-Data Report A K-82-1. 1994, Water resources data for Alaska, water year 1993: U.S. Geological Survey Water-Data Report AK-93-1, $373 \mathrm{p}$.

Viereck, L.A, and Little, E.L., 1972, Alaska trees and shrubs: U.S. Department of Agriculture, Agriculture Handbook No. 410, 265 p.

Wahrhaftig, C., 1965, Physiographic divisions of Alaska: U.S. Geological Survey Professional Paper 482, 52 p.

Waller, R.M., and Tolen, D.A., 1962, Data on ground-water exploration and development in southeastern Alaska: U.S. Geological Survey Hydrological Data Report 19, 15 p.

Yehle, L.A., 1974, Reconnaissance engineering geology of Sitka and vicinity, Alaska, with emphasis on evaluation of earthquake and other geologic hazards: U.S. Geological Survey Open File Report 74-53, 104 p. 


\section{APPENDIX 1}

Text of a 1942 letter to the Navy regarding availability of ground water on Japonski Island 


\author{
UNITED STATES \\ DEPARTMENT OF THE INTERIOR \\ GEOLOGICAL SURVEY \\ WASHINGTON
}

\begin{abstract}
Memorandun concerning the ocourrence of ground water on
\end{abstract}

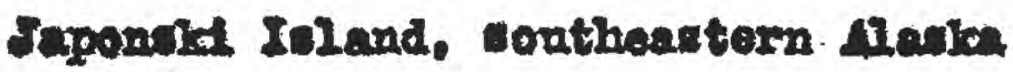

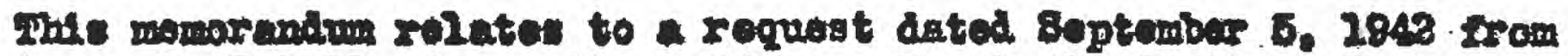

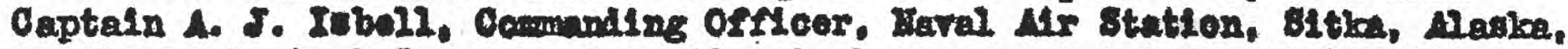

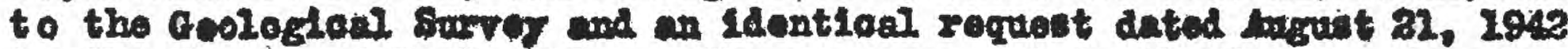

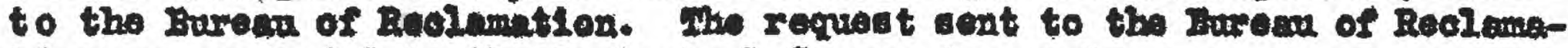
$t$ Lon was roferred to the Gelegleal Brorey for repls.

It it underetood that the U. 8. Havg detres to obtaln a exply of

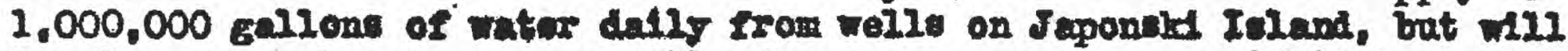

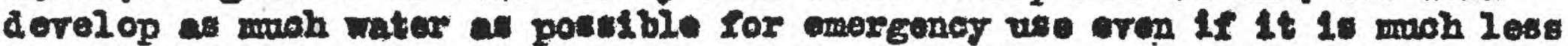
than 1,000,000 gallon deily. Mr.J. C. Heod, Ilankan Hranoh, Geologlcal 8trvey, made a brief imvestigation of the geology and cocurronoe of ground water on Japonsul Inland. Mr. Reod trantmitted Mi flading in the form of a memorandur to the Dlrwetor of the Goological Swrrey and nibulted a copy of the monoramin to the Commending Offlcer at 81tka, wh the understandIng that orlug to the virgent need for the information the material was belng released without pilor apgroval by the Director of the Geologicel survey. Whon Mr. Reed returned to Neshington ho conferred with goologists of tho Nater Rascurces Branch of the Goologlcal survey, and the baslc geologic and hydrologlc date ware carefuldy tudled. The following tatement was prepared Jointly by the two brenches:

The available date thow that in general the bodrock on raponskl Inland consists of rether denwe hard rock that has a northwosterly etrike and dips about 70 degrees to the sonthest, but in a few localit1es the rook dipe steoply toward the nortboset. The bedrock ho a rory low permeability and torage capacity, but it has been fractured rather extensively and ome ground water occurs in the opening formed by the fractures. A tone of relatively Intensely tractured rock occurs in the eastern part of the 1aland and trends epproximately north. In most places on the 1aland the bedrook is orerlain by thin glacial depost te wioh in eme places are overlaln in turn by rolcanio deposits. The gicelel and roleanic doposits are relatively impermeable and vill yield littie or no round water.

The geologle struature indicates that it is very milbely that any ground water reaches Jeponill Icland anderflow frow the malniend (Raranof Island). Honce any ground water that occurs on Japonskd Island is dorived from rainfall

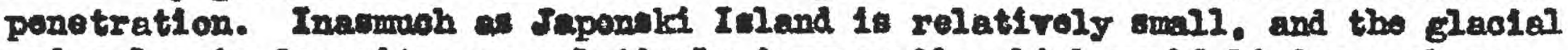
and rolcanic deposit are relatively imparmeable which would hinder recharge, It appears thet the development of contimous mpply of $1,000,000$ gallons dally, or even of a conlderably smaller continuous ouply. from welle lo not practicable. Fello in the bedrock will not yleld any large eupplies unlese large or very muneroul fractures are encountered, which seem unlikely. However, 
It way be posible to arrelop mall supplies of potable water. or falriy

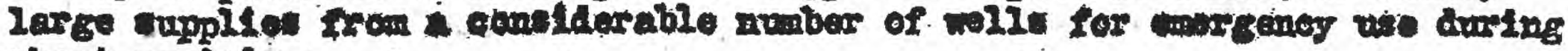
nhort pariodi:

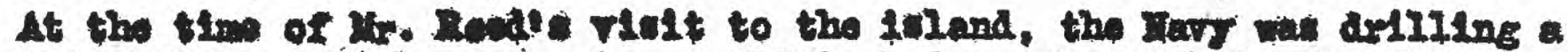
3-Inch test hole, widek on ootobur 8. 1942, had reached the dopth of 230 reot. It was reported that witur was encountered at a depth of 180 foot and that

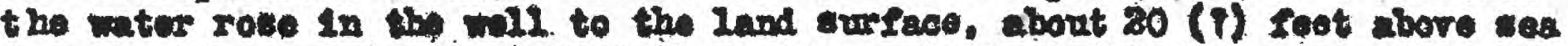

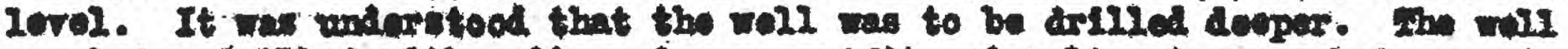

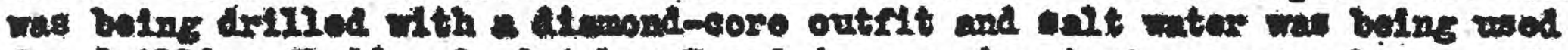

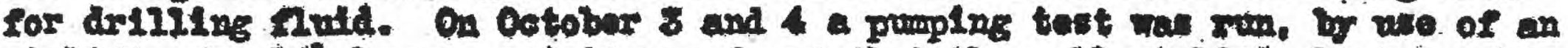

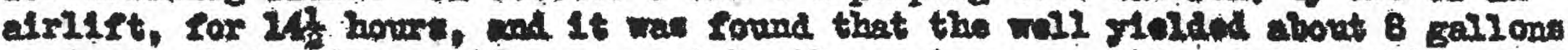

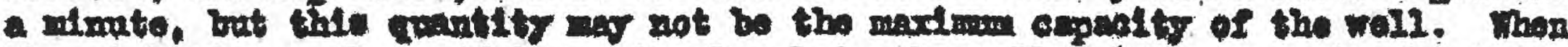

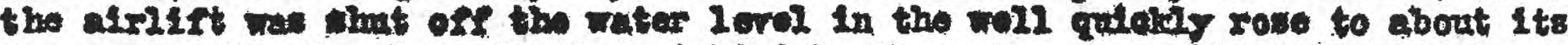
former. Ierel. Bunglet of water Jielded by the woll wro eoll ceted at varlous

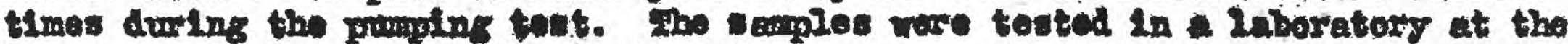

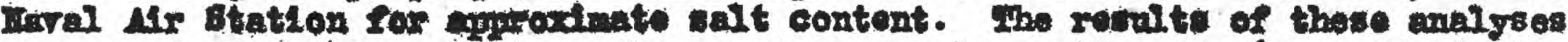

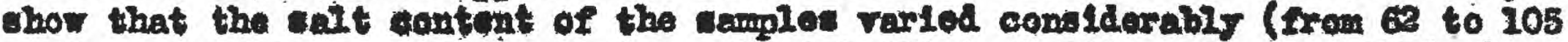

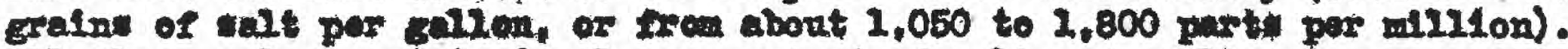

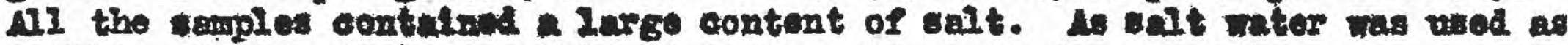
drilling Iluld, it it posilble that the salt content mas not be representative of the water that ocowe natrually in tho rocka.

On maxy mall 1elende monlain by permeable rooks that we froely connected with the coean. it is posesibie to determine the aproximate depth to salt water by lnowing the alevation of the water table. Ondinarily there is about 40 foet of fresh water below sea level for overy loot of frenh water above sea lerol. On Jeponild Irland this principle mas not epply becaves the bedrook probably becones 10 st Irwotured with depth.

In order to determine bet locellties for fround-water development It is desirable to drill serwal thallow test holes in the rone of fractured rock on the east mide of the 1aland and in other areas whlch may also be underiain by Intensely trastured rocke: Tho diamend-core outfl that is already on the leland will be catisfactory for this purpose, but the Z-inch walls will not gleld we woh water as wolls of larger diamater, weh as wovld be drilled by the $\operatorname{man}$ or cule tool method. For production wells, diemsters of 6 to 10 inches are recommended. It 1s recormended that the wells be drilled no depper than bout 300 feet. The drilling fluld sovid be fresh water in order to arold contemination of the ground water.

Careful record ahould be made of the chrracter of the rooke at suoces stre depths 80 as to obtaln Information as to tho Intenel ty of Ireaturing and the copths at wich the rracturling occurs. As soon as water is oncounter od, a somple of the water hould be colleated and tested for enl content. Whe well should be teeted for about 15 minutes for gleld. by baliling or alrilft, at approxinately the follonins depth, in feot, bolow the level at which the flrst water was eneounteredt 25, 60, 100, 150,200, 250, and 800 reet. Semples of water hould be collected near the ond of oach biling or pruping test. Whon the well is completed promping test of about one hour duration should be rum. and tests of longer duration may be deslrablo on some wolle. In the final pumping teste samples of water hould be colleoted soon aftor the test has been started and again at the wh of the test. In testing each wil for flold the water Ievel in the.well ohould be measured before proming 1s sterted and the rate of recovery of the water level shovld be determined by maling a verles of 
mearuremont after propling has been stopped. The rate of recoven of the

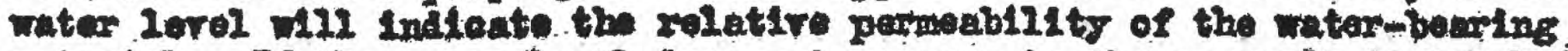

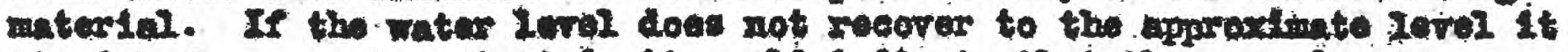

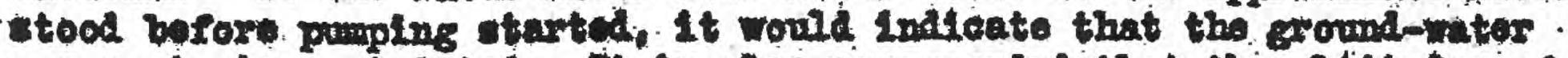

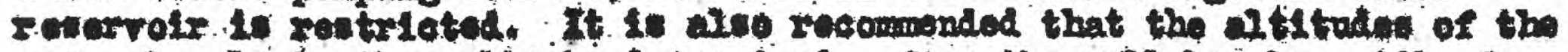

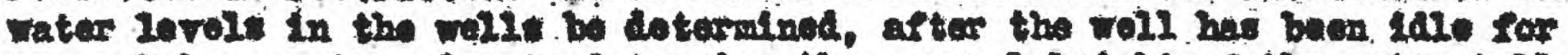
eeveril howr, in order. to deternine the general holght of the vater table.

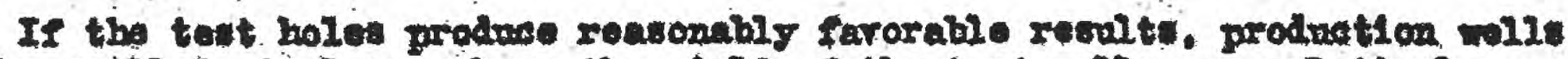
way be dillad at places where the rield of the test wall was relatively Iarge and the ent dontent of the vater relatively low. The weile whould be placed as far troin the wint as prestloable end where the water table is

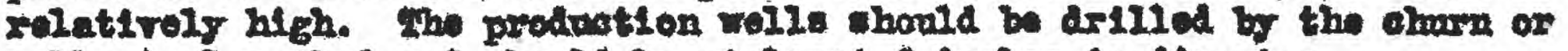
cable tool method and hould be at least 6 inches in dienoter.

the Geolodeal Survey w1I be glad to belp Interaret the lath obtalued In tho test drilling. It is suggetted that a rocord of each woll be treng-

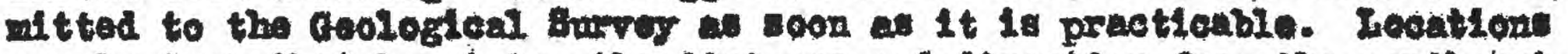
way be described by giving the distance and direction from the nor thiset oorner of the Valntenante butldine on Japonskl Islond. Samples of water may also be sent to the Coologloal Survey for chemical analyis. It is desirabie that fleld tests of the walt content of the same samples be run for comparison W th the analyean to be mad in the Laboratory of the Goologleal Burvey.

Detober 22, 1942.

For Navy

JCR:RRB: OEM: gC
John C. Reed

Senior Geologist

Robert R. Bennett

Assistant Goologist 


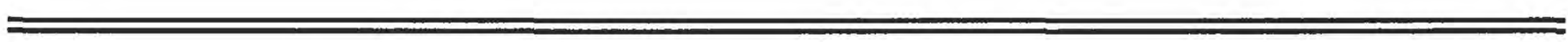

APPENDIX 2

Water-quality data for surface water near Sitka, Alaska 


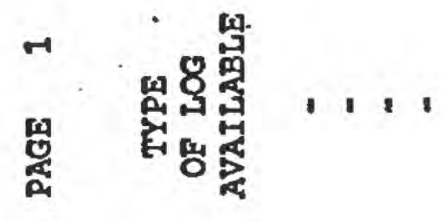
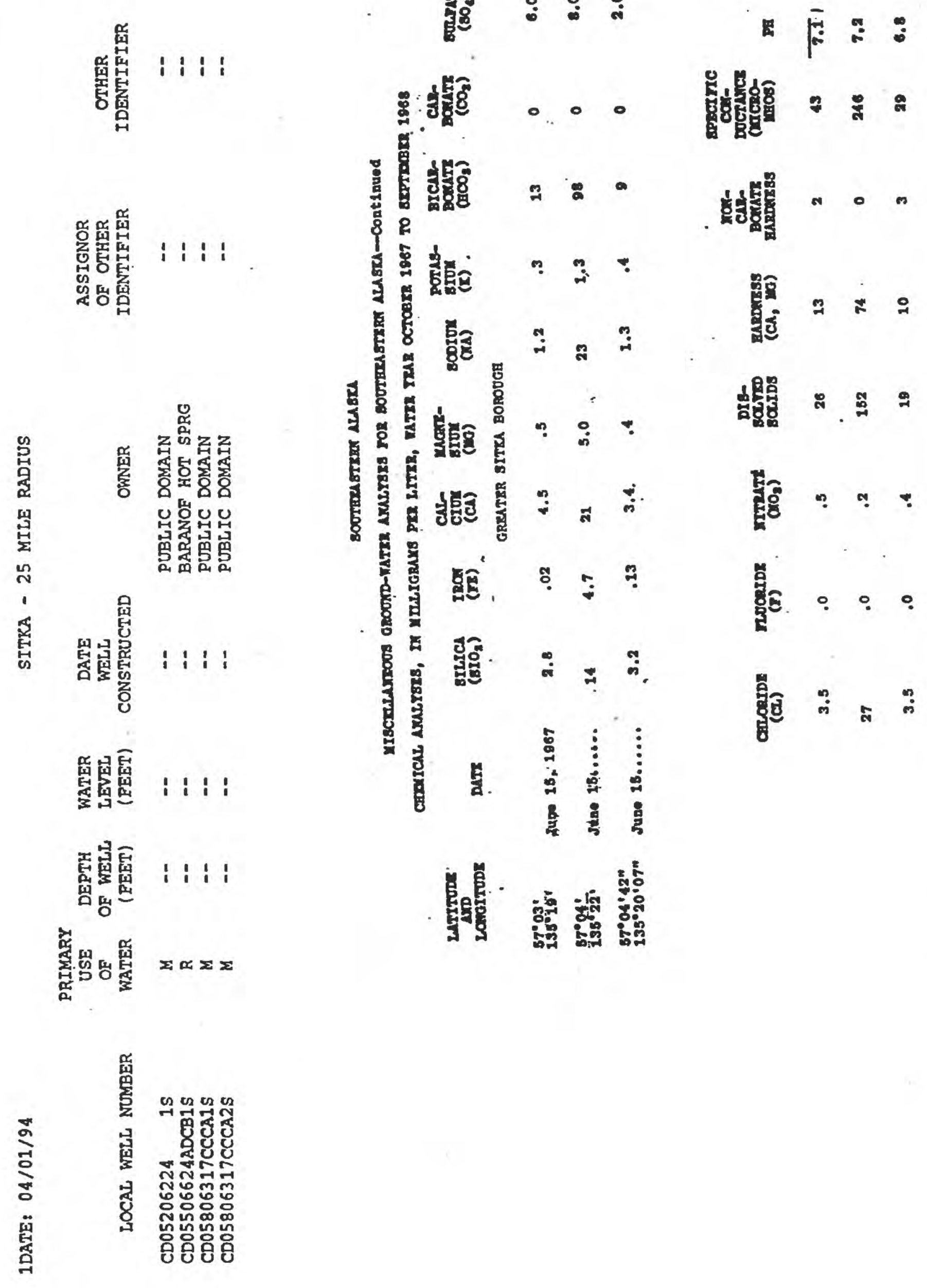


\begin{tabular}{|c|c|c|c|c|c|c|c|c|c|}
\hline 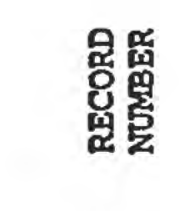 & 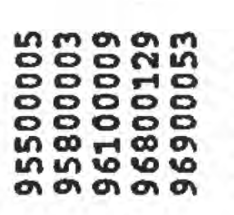 & $\begin{array}{l}\text { 心 } \\
0 \\
0 \\
0 \\
\vdots \\
\vdots\end{array}$ & 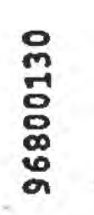 & 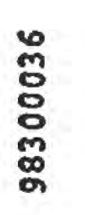 & 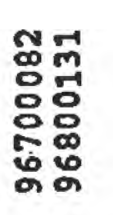 & 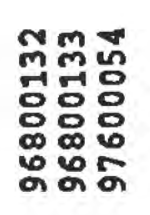 & 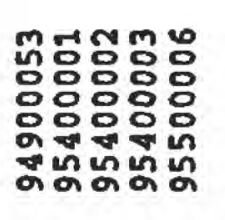 & 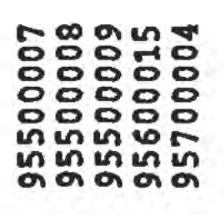 & 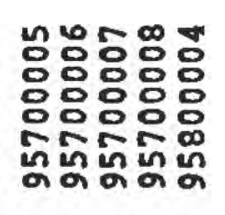 \\
\hline 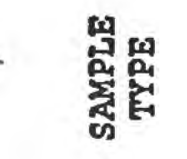 & anoara. & a & a & $a$ & an & ana & anaga & anama & 00000 \\
\hline 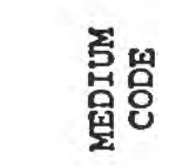 & 00000 & $a$ & $a$ & $a$ & on & ana & 00000 & 00000 & 00000 \\
\hline \multirow{8}{*}{ 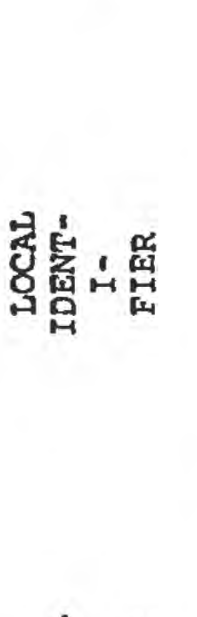 } & & & & & & 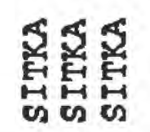 & & & \\
\hline & & 索 & 差 & 录 & 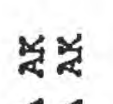 & 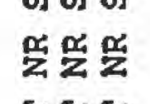 & 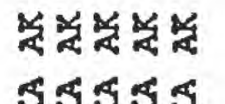 & 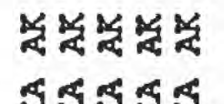 & 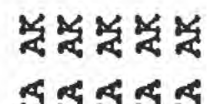 \\
\hline & 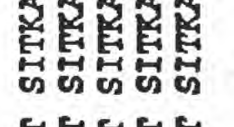 & 㥕 & 溹 & 悤 & 急急 & 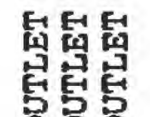 & 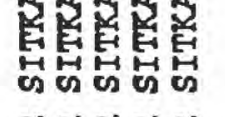 & 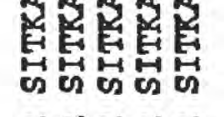 & 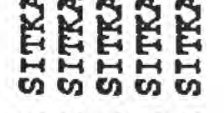 \\
\hline & 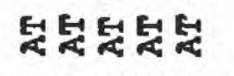 & 舁 & on & 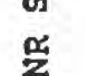 & E & 808 & 㸒爱愛品品 & 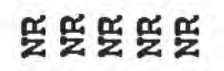 & 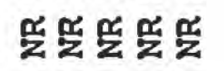 \\
\hline & 00000 & 0 & 告 & $\begin{array}{l}z \\
\alpha\end{array}$ & 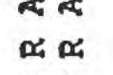 & 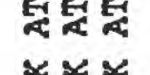 & 00000 & 0.0000 & บ0000 \\
\hline & 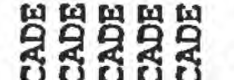 & 剀 & 岸 & z & 学 & 杀号曾 & 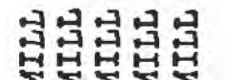 & 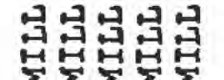 & 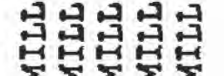 \\
\hline & 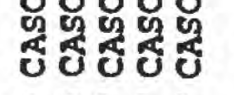 & ช్ & 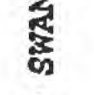 & 兽 & 惫 & 㟔㟔㟔 & 芯秋芯 & 心秋秋心 & 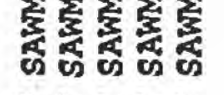 \\
\hline & 333 & 3 & 3 & 3 & 33 & 333 & 33333 & $3 x$ & $x \geq 3 x 3$ \\
\hline \multirow{4}{*}{ 总的罟 } & $\stackrel{\infty}{\infty}=$ & 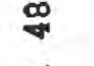 & $\approx$ & ฟै & ถิก ถิ & ัํํำ & 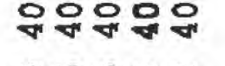 & 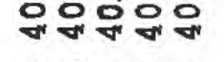 & 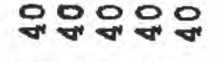 \\
\hline & $\vec{N} \tilde{N} \vec{N} \vec{N}$ & $\vec{N}$ & i & $\tilde{F}$ & $\stackrel{\infty}{\rightarrow} \underset{\sim}{\infty}$ & テ F F & 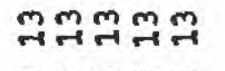 & 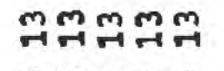 & 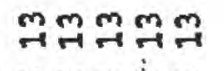 \\
\hline & m & $\stackrel{n}{m}$ & $\stackrel{n}{\rightarrow}$ & $\stackrel{\sim}{\text { m }}$ & $\stackrel{n}{\sim} \underset{F}{m}$ & 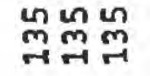 & 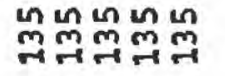 & 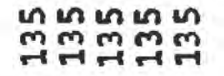 & 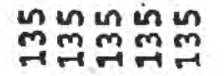 \\
\hline & $z z z z z$ & $z$ & $z$ & z & $z z$ & $z z z$ & $z z z z z$ & $z z z z z$ & $z z z z z$ \\
\hline \multirow{3}{*}{ 寄的罳 } & กลลกล & $\approx$ & 무 & 5 & 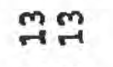 & $\stackrel{\infty}{*} \stackrel{\infty}{*} \mathbb{q}^{\infty}$ & ํํㅇํㅇㅇํํㅇํㅇ & 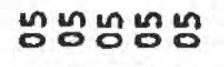 & ํㅗㅇ농ํํㅇำ \\
\hline & ガずઠ゙ல゙ず & D & m & \& & mo & m & ๓ロロロ๓ & ๓ュ๓๓๓๓ & 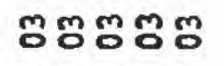 \\
\hline & 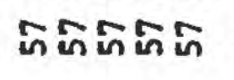 & n & in & in & 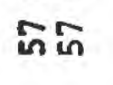 & in in & 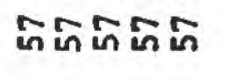 & 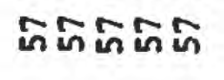 & 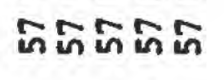 \\
\hline 幽 & |'：品号 & : & $\stackrel{\circ}{\circ}$ & : & : & 品 & 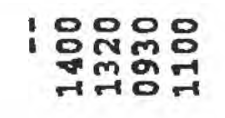 & 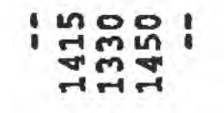 & 1:1:1: \\
\hline 與 & 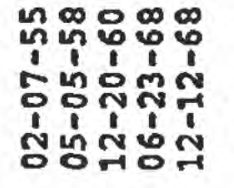 & 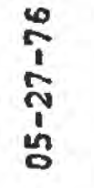 & 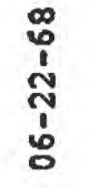 & 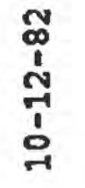 & 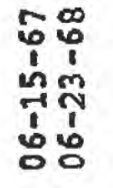 & 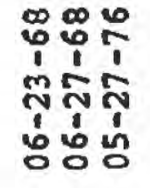 & 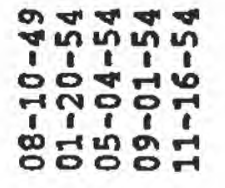 & 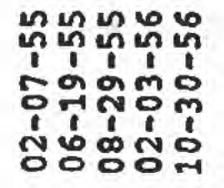 & 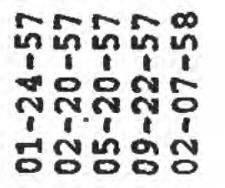 \\
\hline & & & & & & & & & \\
\hline 总 & 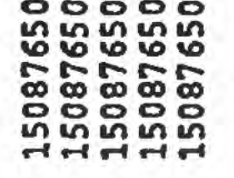 & 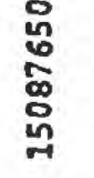 & 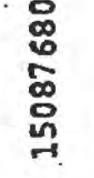 & 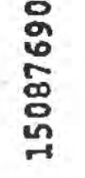 & 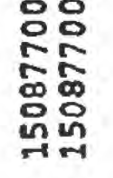 & 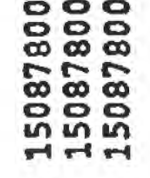 & 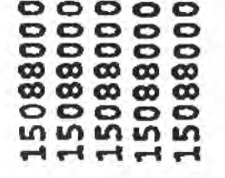 & 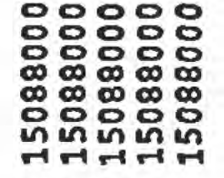 & :응ㅇㅇㅇㅡ. \\
\hline
\end{tabular}




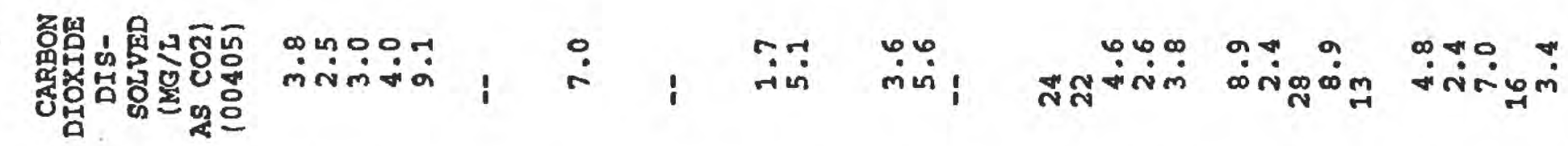

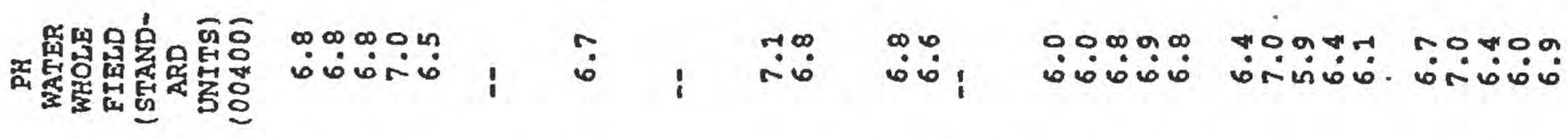

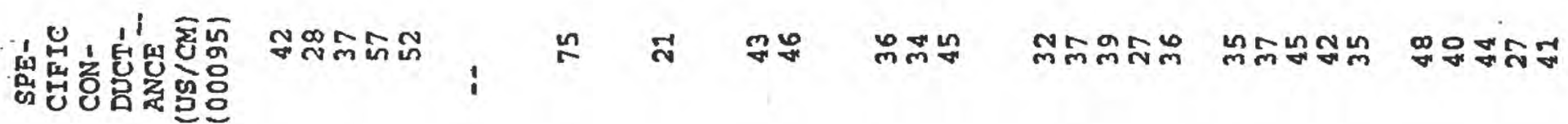

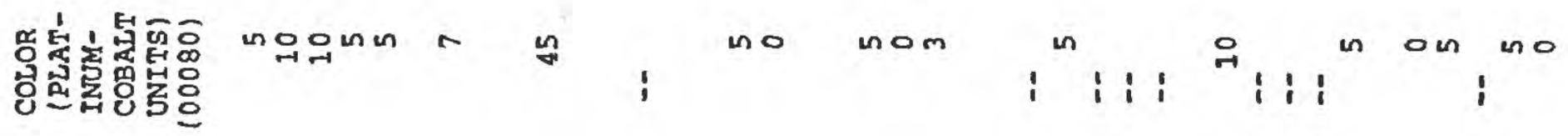

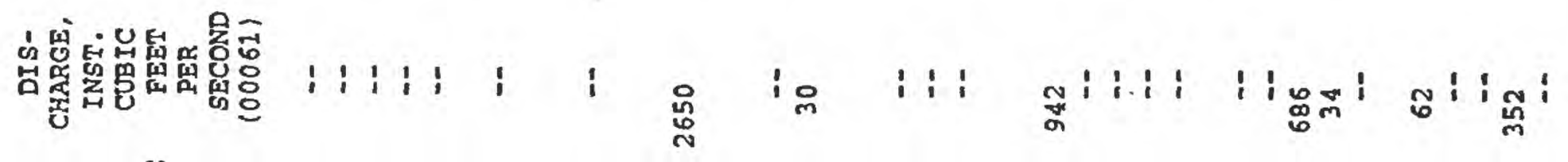

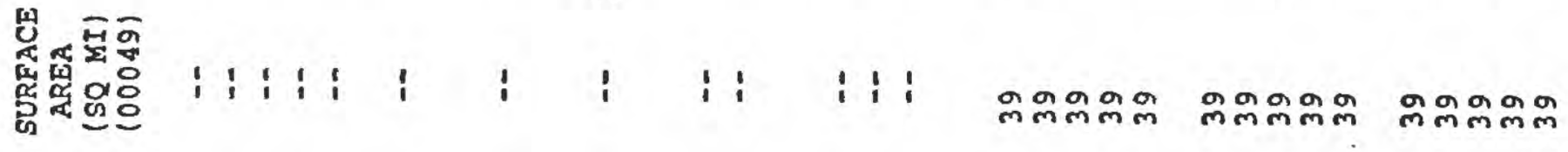

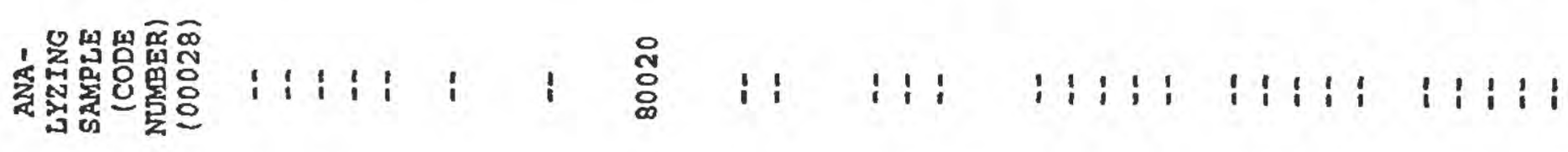

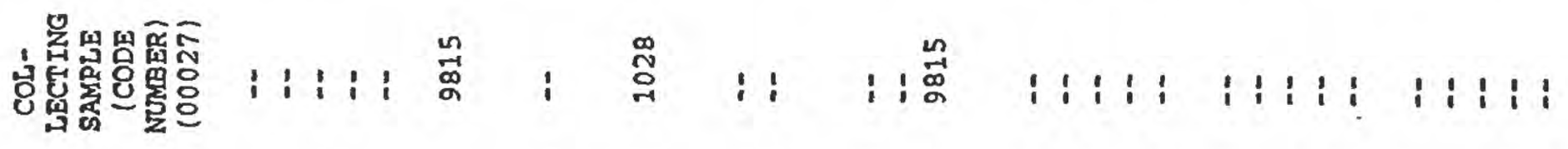

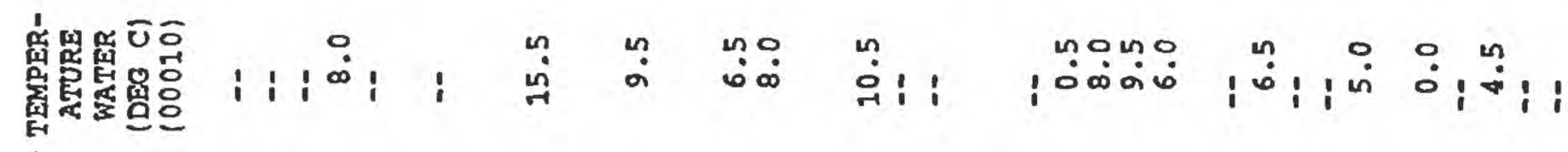

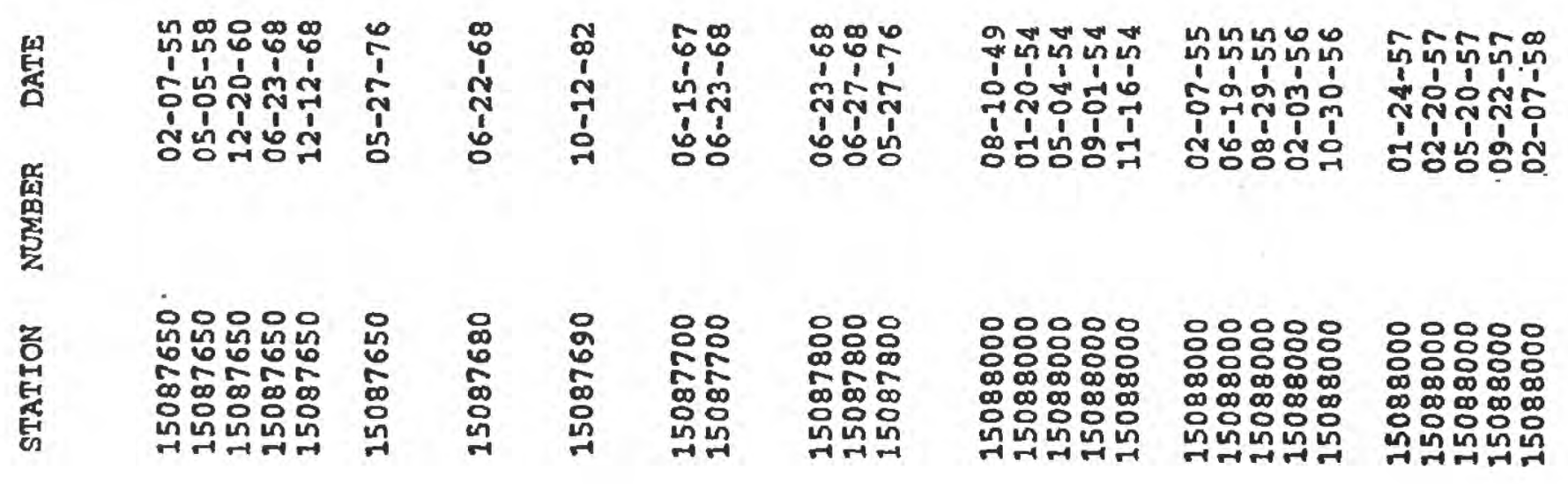




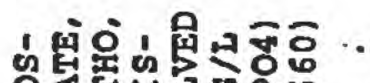

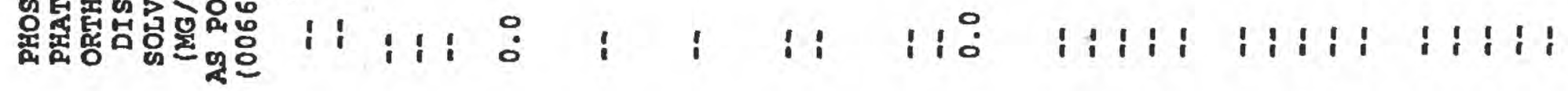

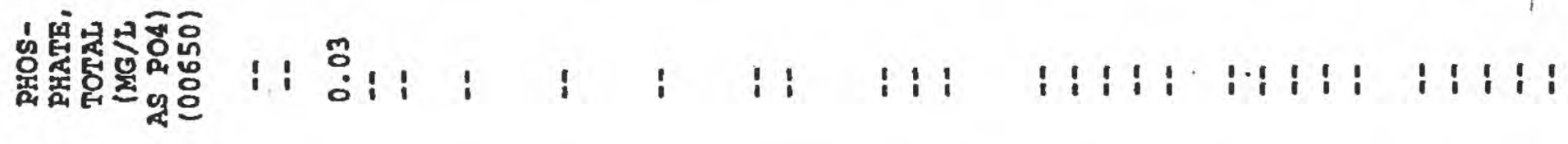

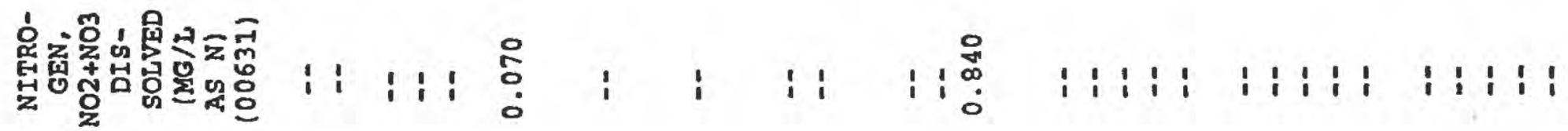

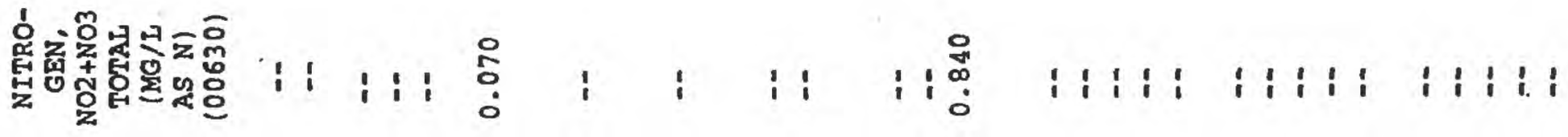

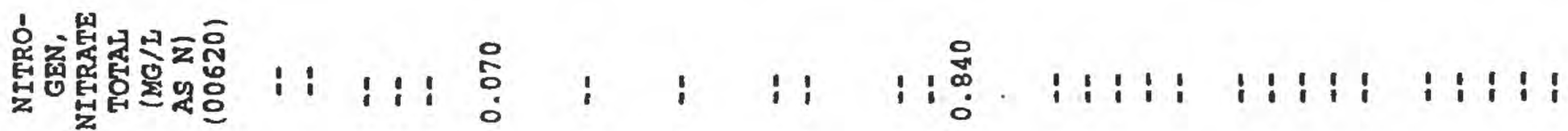

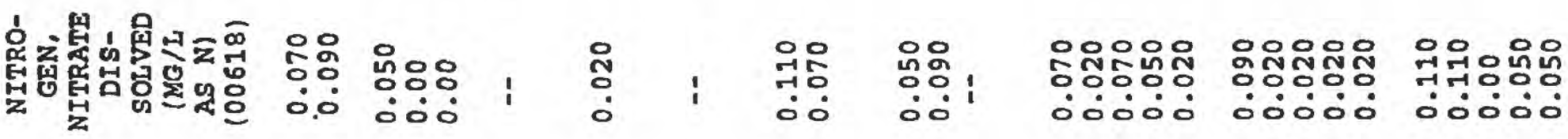

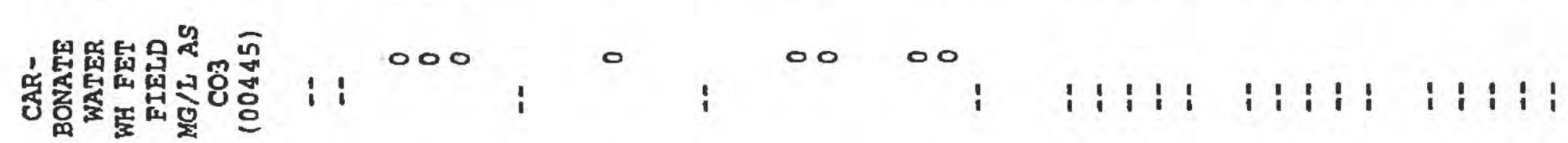

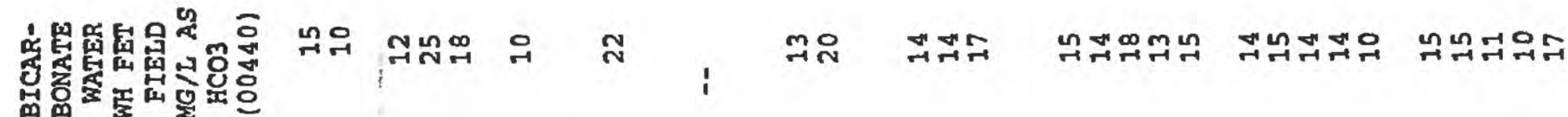

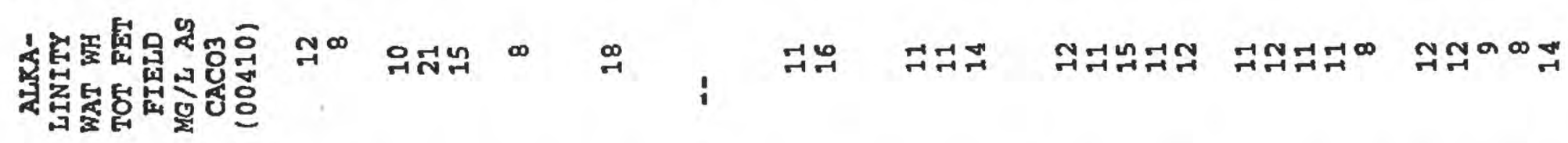

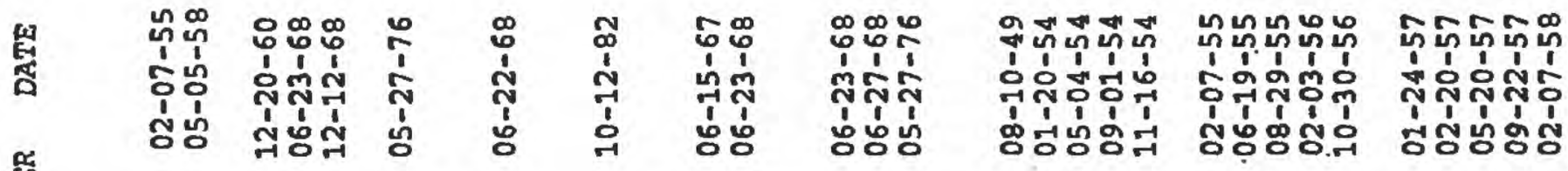
鳃

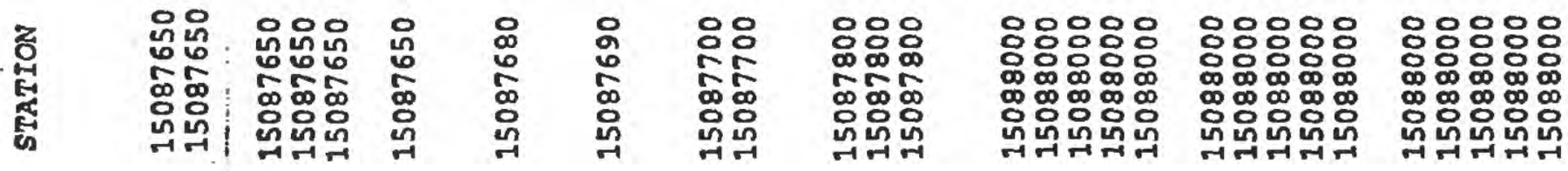




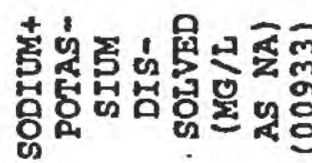

i: $1: 1:$ i $1:$ it:

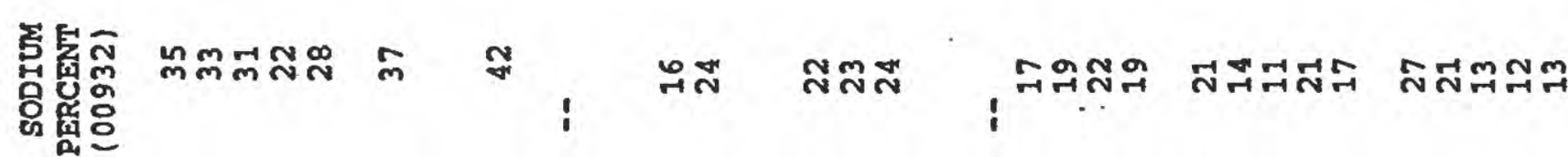

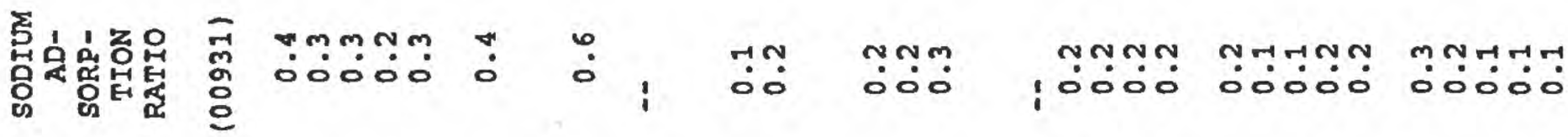

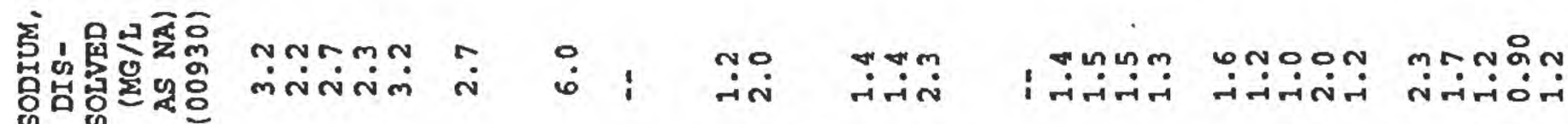

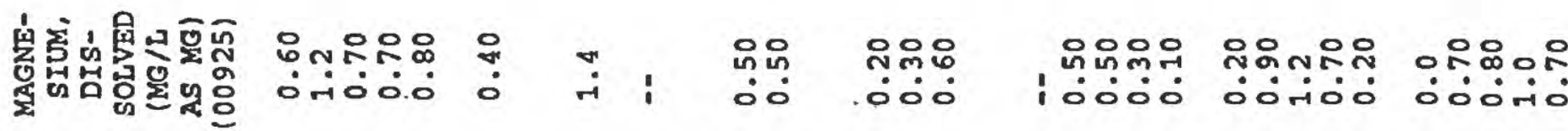

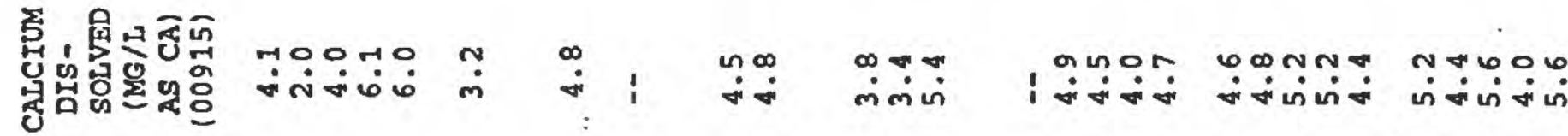

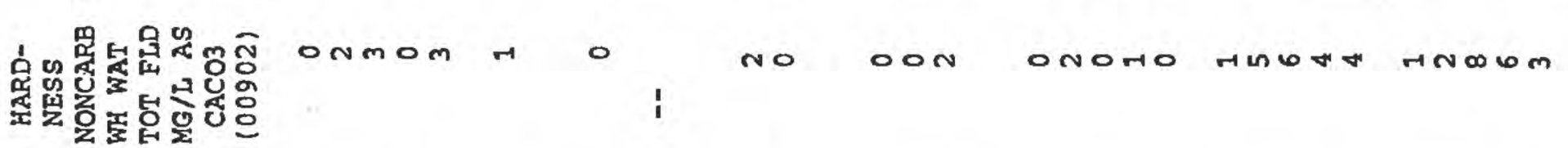

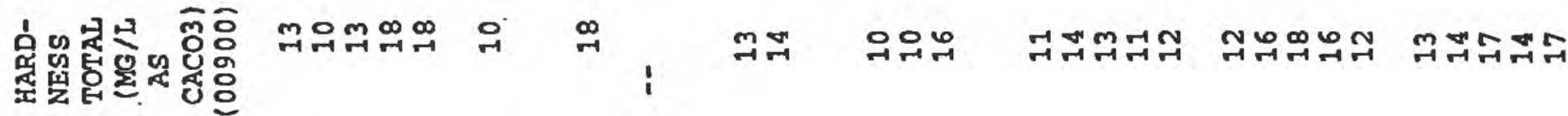

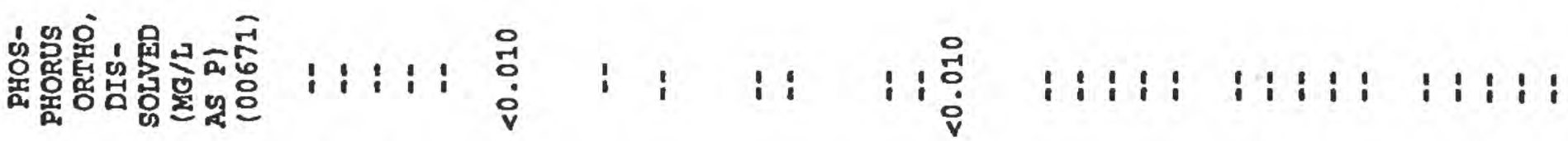

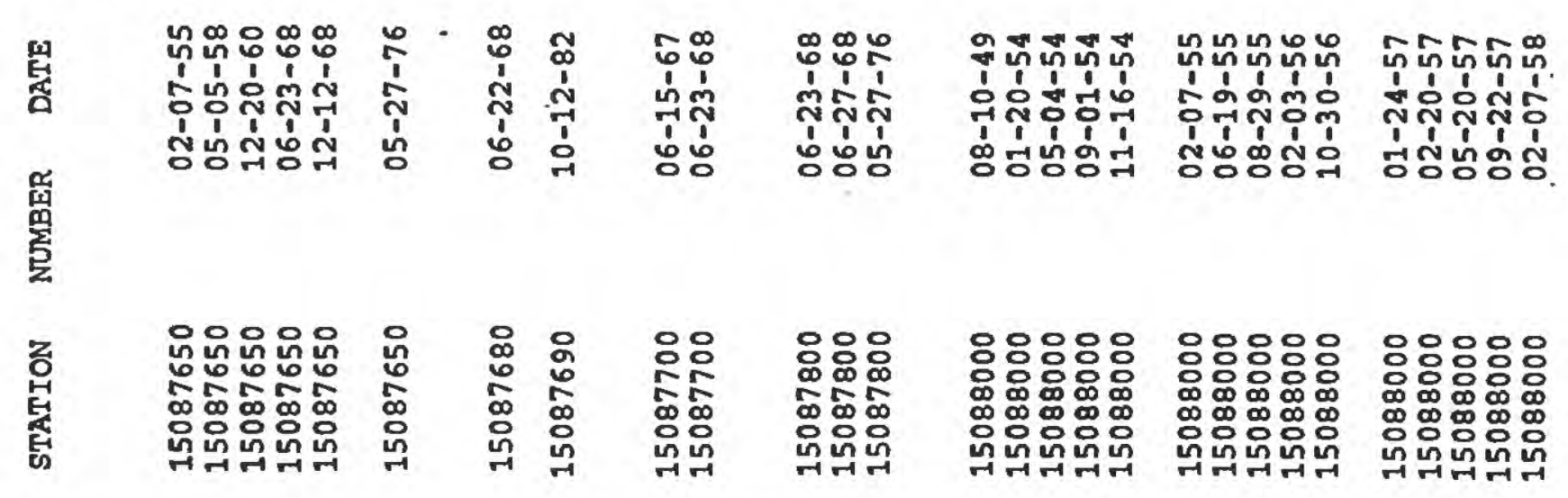




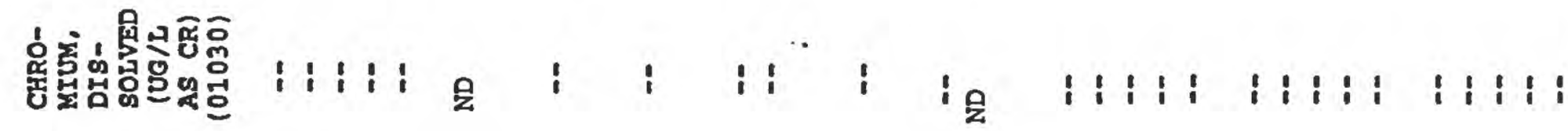

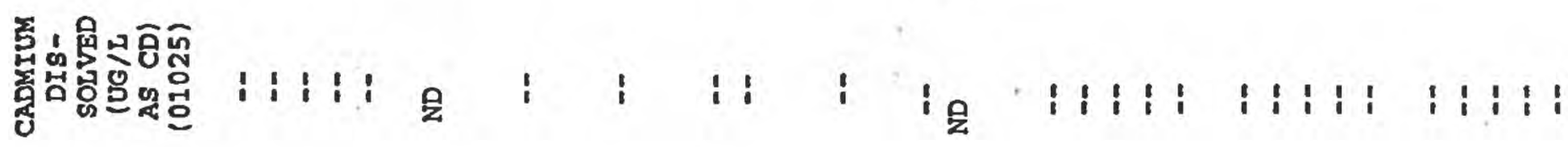

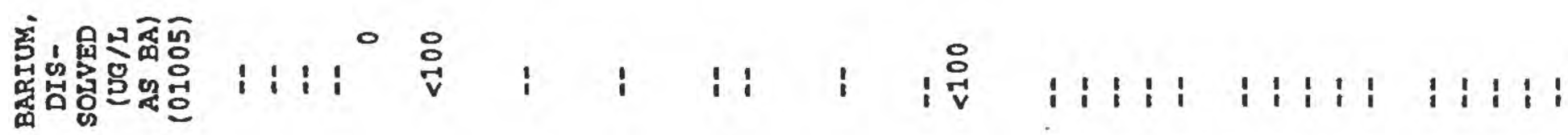

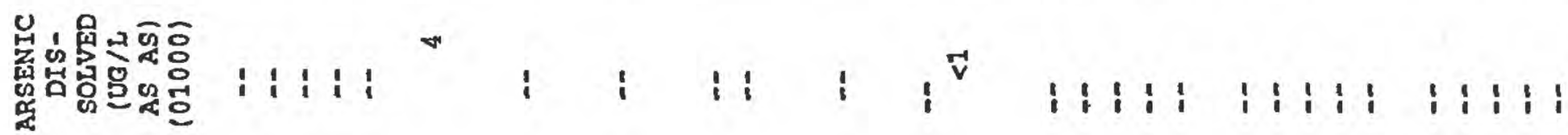

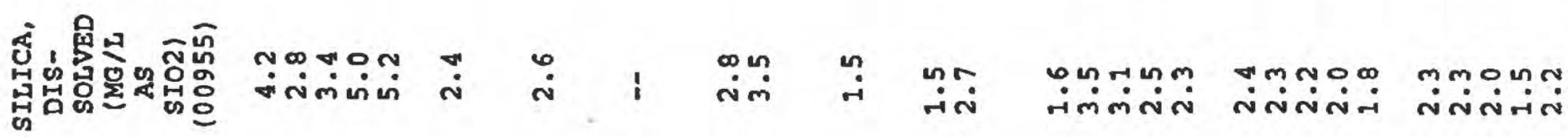

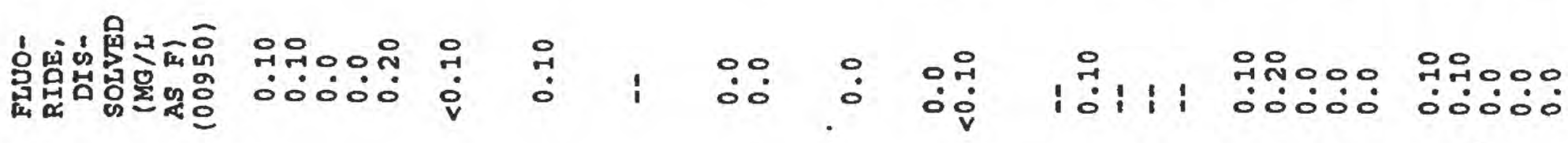

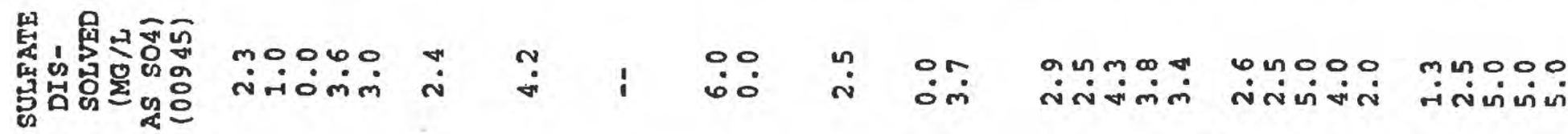

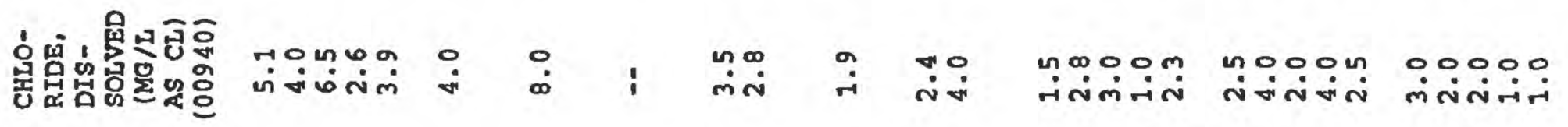

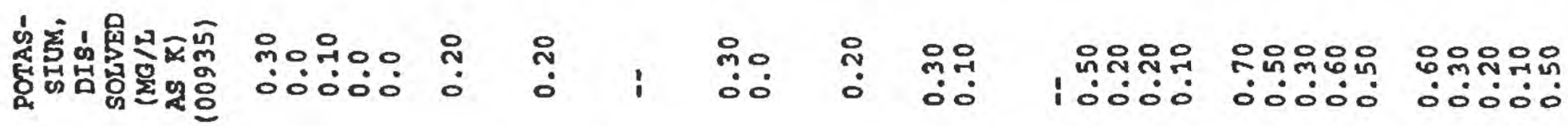

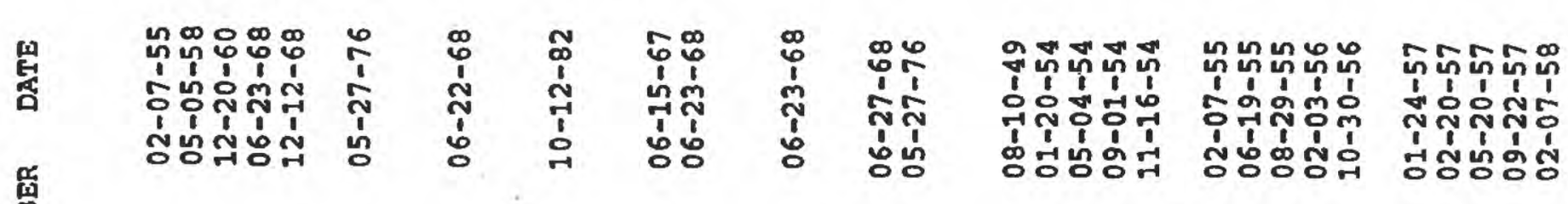
敛

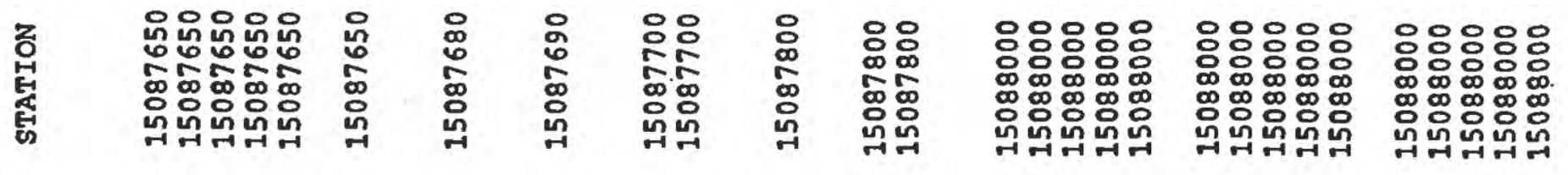




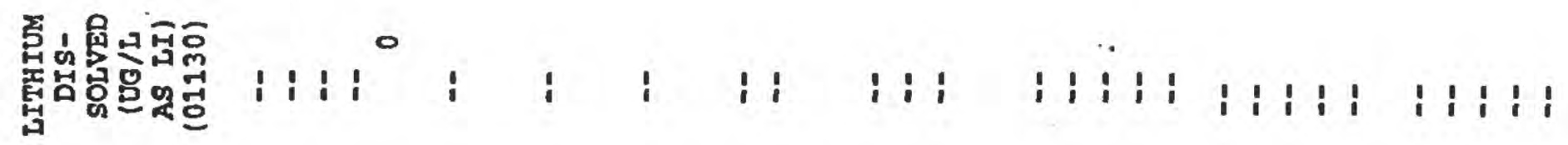

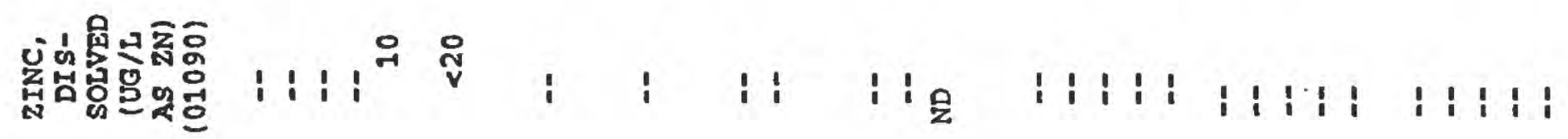

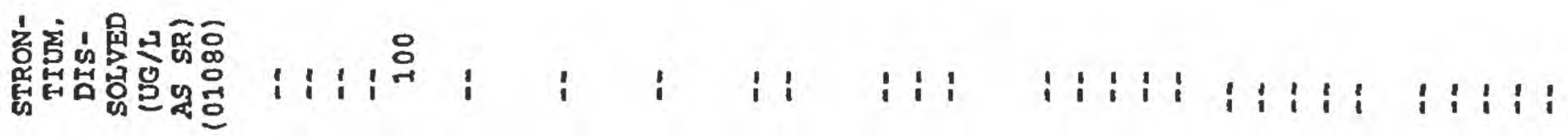

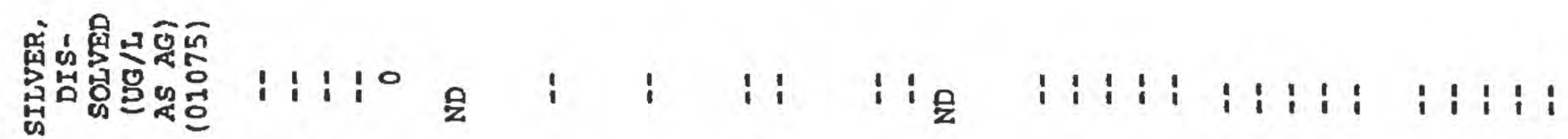

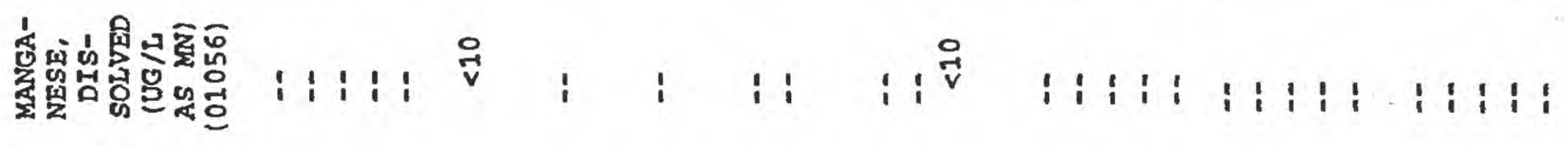

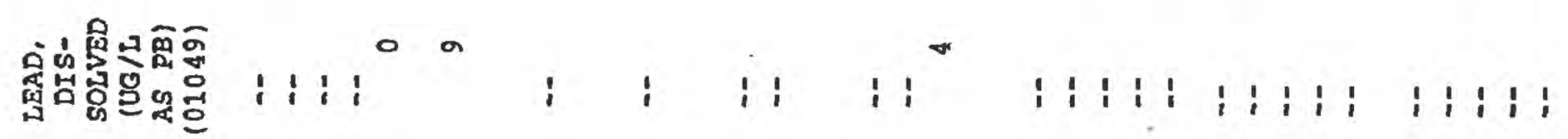

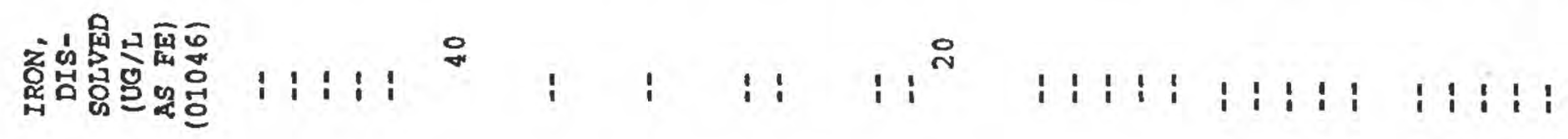

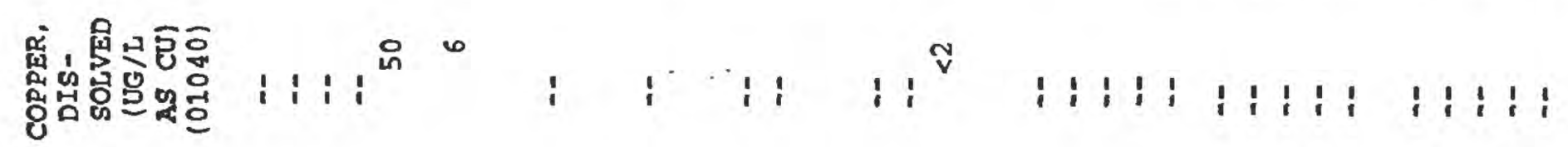

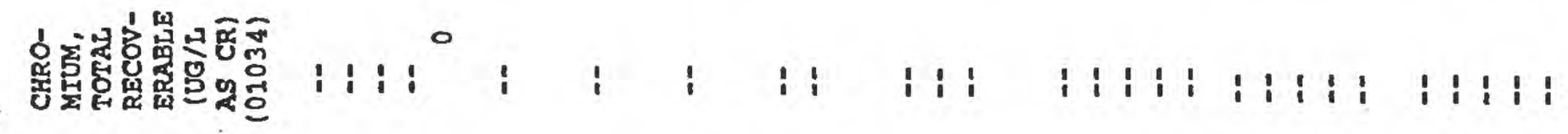

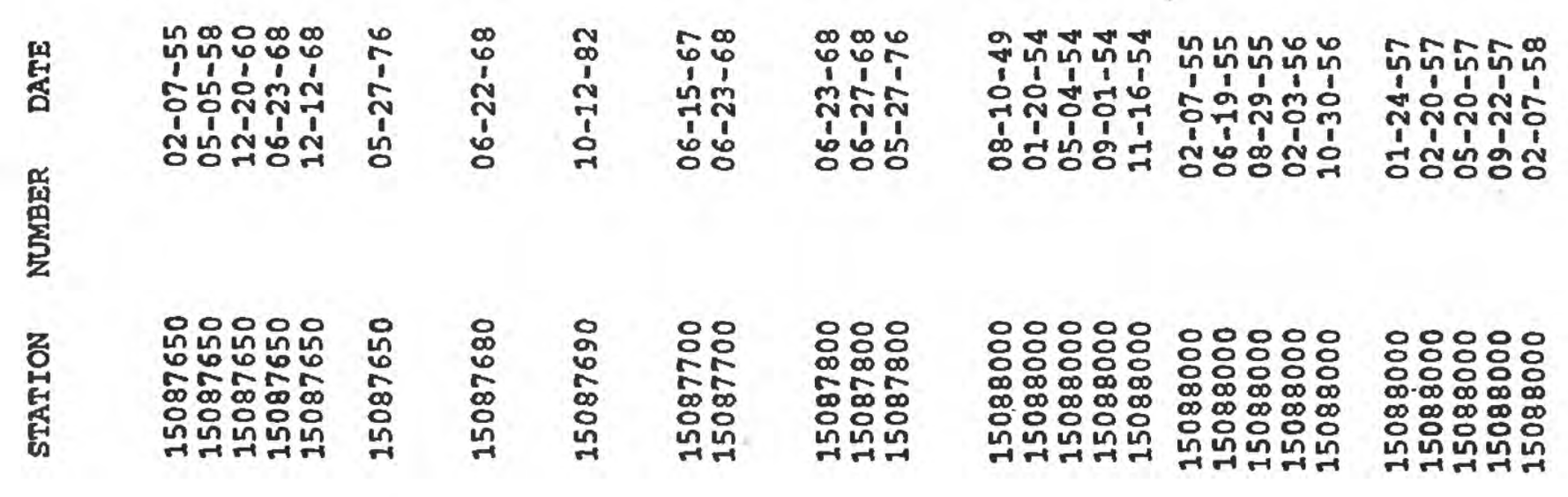




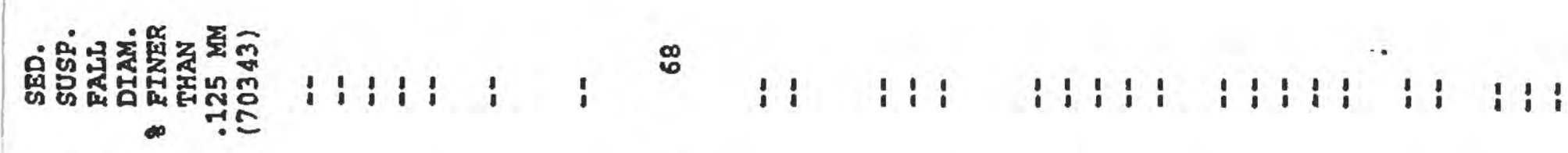

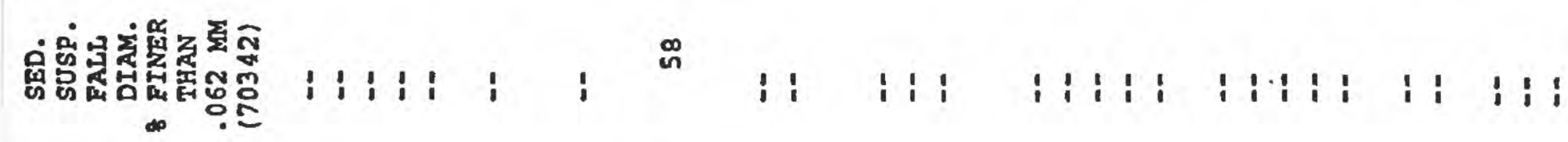

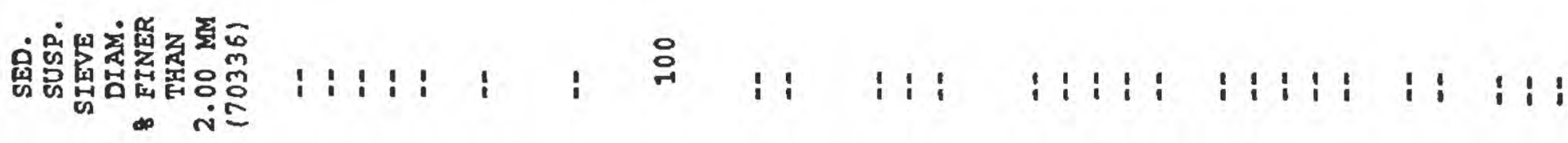

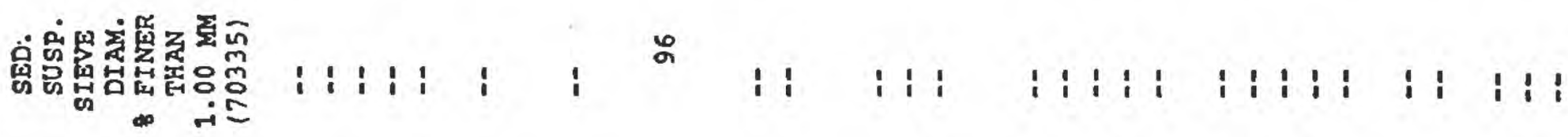

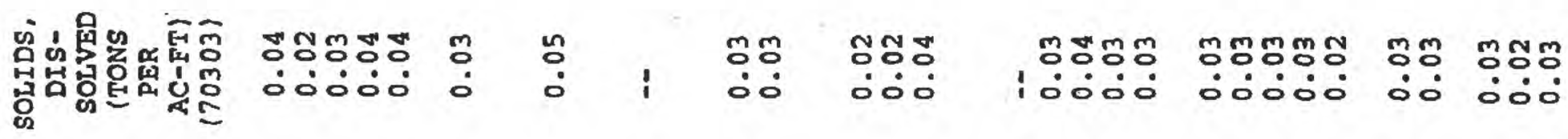

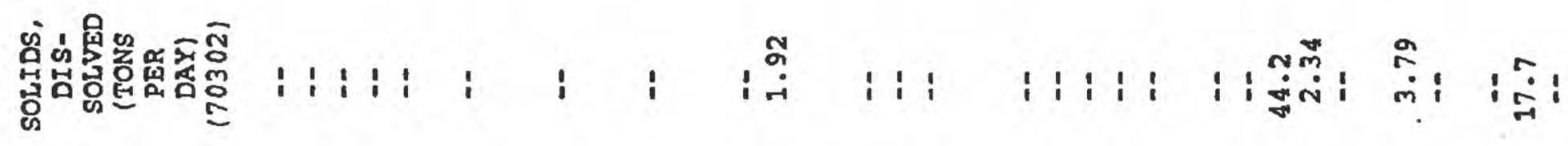

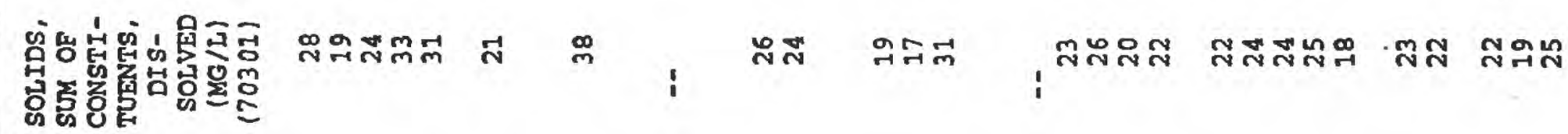

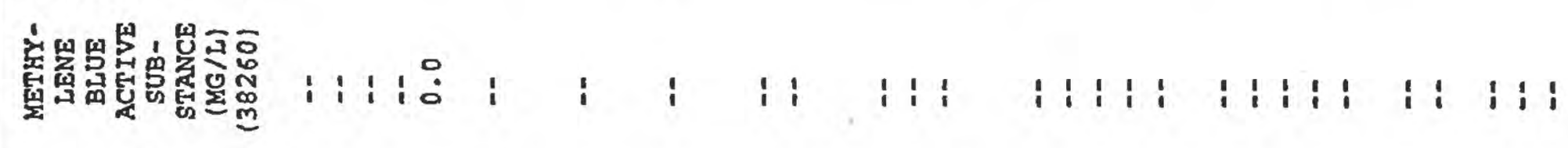

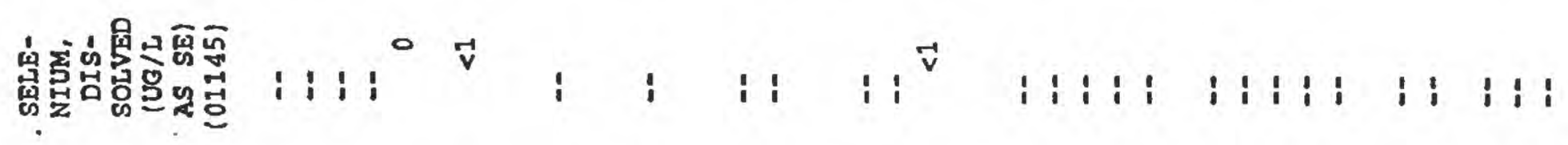

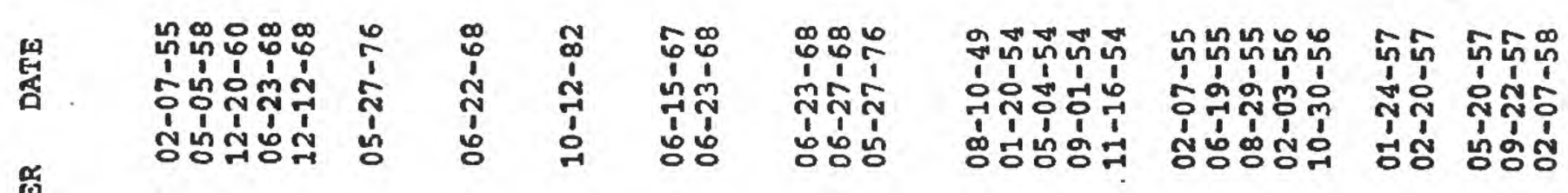
怘

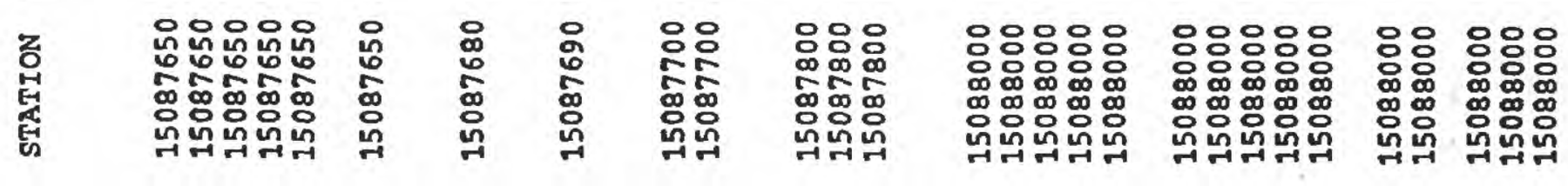




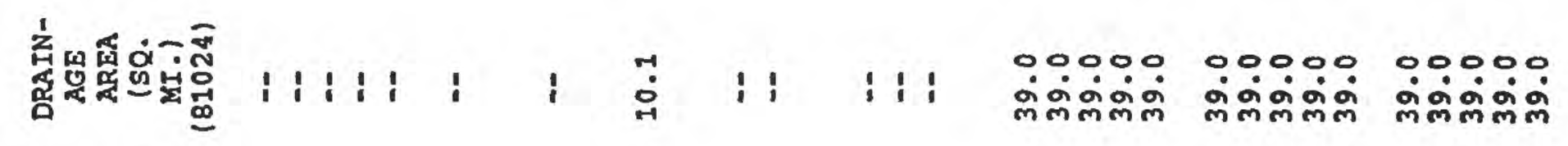

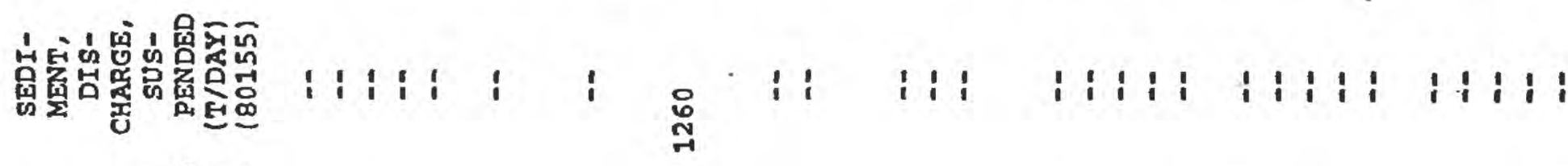

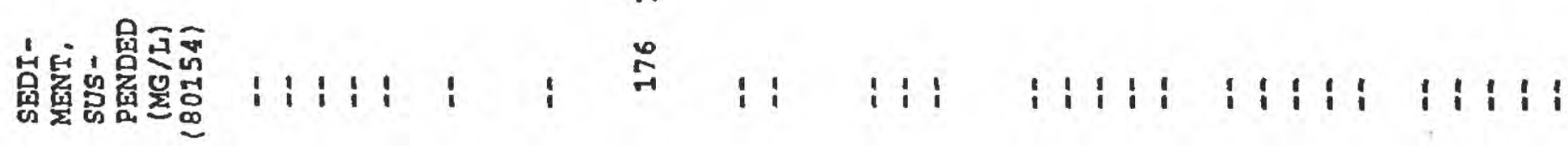

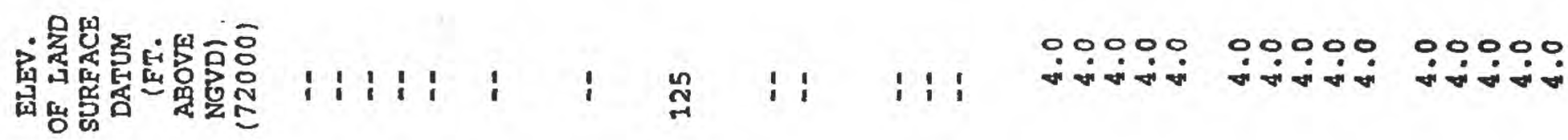

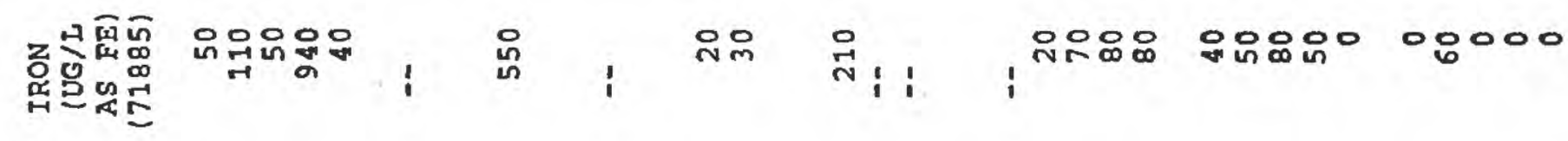

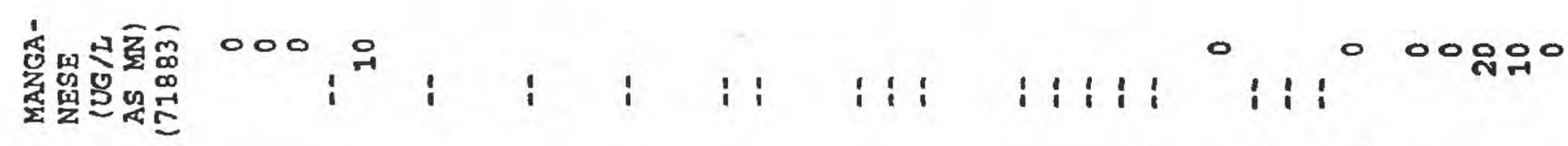

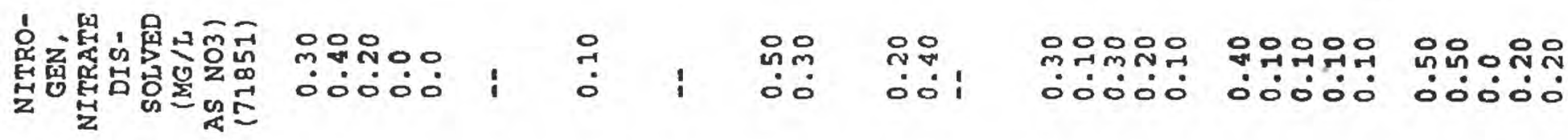

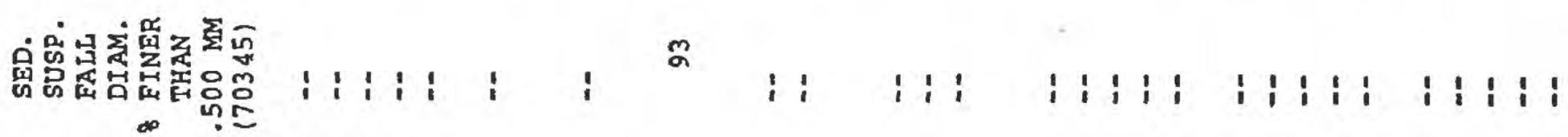

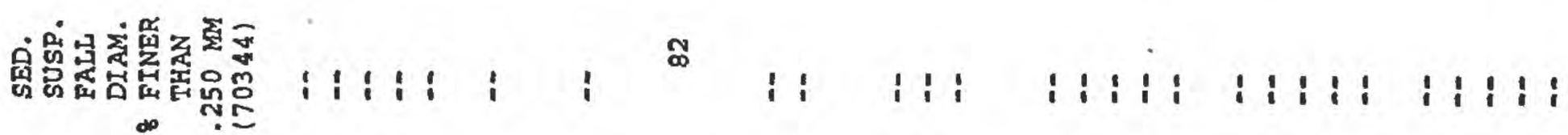

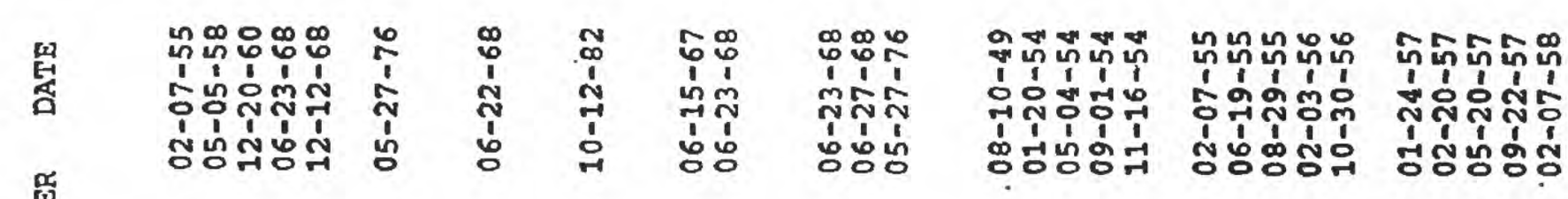
1

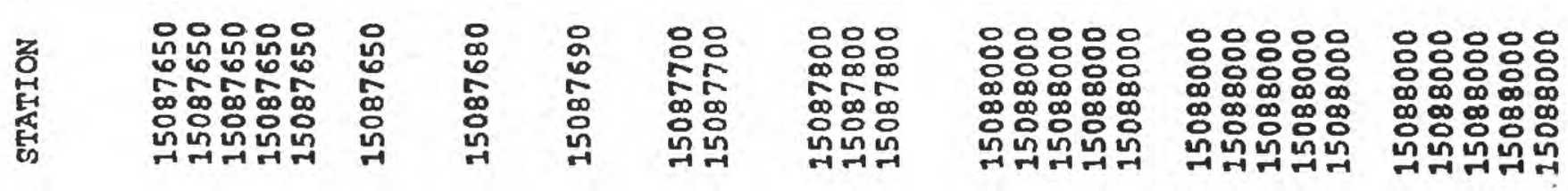

